\title{
Compositional Differences between Felsic Volcanic Rocks from the Margin and Center of the Northern Main Ethiopian Rift
}

\author{
*Kurkura Kabeto ${ }^{1,2}$, Yoshihiro Sawada ${ }^{2}$, Barry Roser ${ }^{2}$ \\ ${ }^{1}$ Department of Earth Science, College Natural and Computitional Sciences, Mekelle University, \\ P.O.Box 231, Mekelle, Ethiopia. (*kurkura57@yahoo.com/ kurkura.kabeto@mu.edu.et) \\ ${ }^{2}$ Department of Geosciences, Shimane University, Matsue 690-8504, Japan
}

\begin{abstract}
Pliocene felsic rift margin and Quaternary rift center volcanic rocks from the northern Main Ethiopian Rift (MER) exhibit contrasts in major and trace element contents and Sr-Nd isotopic ratios. Quaternary rift center felsic volcanic rocks are mainly peralkaline trachytes and rhyolites, whereas Pliocene felsic rift margin volcanic rocks are represented by benmoreites, weakly peralkaline trachytes and rare rhyolites.

Most of the felsic rift margin volcanic rocks have greater $\mathrm{Al}_{2} \mathrm{O}_{3}, \mathrm{~K}_{2} \mathrm{O}, \mathrm{Nb}, \mathrm{Zr}, \mathrm{Rb}$, and $\mathrm{Sr}$, and lesser $\mathrm{CaO}, \mathrm{Zr} / \mathrm{Nb}$, and $\mathrm{CaO} / \mathrm{Al}_{2} \mathrm{O}_{3}$ than rift center volcanic rocks. These contrasts may have been inherited from differences in the compositions of their parental basic magmas, which were produced by variable degrees of partial melting.

In both series, the felsic volcanic rocks generally have higher initial Sr- isotopic (0.7038-0.7073) ratios than their basic equivalents (0.7035-0.7046). Nd- isotopic ratios of most felsic rift center samples (0.5129-0.5126) are similar to their associated basic volcanic rocks. In contrast, the Ndisotopic ratios (0.5128-0.5124) of felsic rift margin volcanic rocks are commonly lower than their companion basic volcanic rocks (0.512806-0.512893), and are relatively lower than rift center equivalents. The elemental and $\mathrm{Sr}-\mathrm{Nd}$ isotopic compositions of the volcanic rocks suggest that fractional crystallization from differing basic parents accompanied by a limited assimilation (AFC) was the dominant process controlling the genesis of the MER felsic volcanic rocks.
\end{abstract}

Keywords: Ethiopia; Northern Main Ethiopian Rift; Bimodal Volcanism; parental difference; Sr-Nd Isotopes, Fractional Crystallisation

\section{INTRODUCTION}

The Main Ethiopian Rift (MER), the Southwestern Ethiopian Rift Zone (SWERZ), the Tana Rift and the Afar region represent the northernmost part of the East African Rift System (Fig. 1). The Ethiopian volcanic province is dominated by up to $300,000 \mathrm{~km}^{3}$ of generally fissure-fed MidTertiary basic $\left(\mathrm{SiO}_{2}<53 \mathrm{wt} \%\right)$ volcanic rocks, and minor associated felsic $\left(\mathrm{SiO}_{2}>53 \mathrm{wt} \%\right)$ products. However, the proportion of felsic products in the Ethiopian rift valley itself is high, reaching about $90 \%$ of the total volume (Mohr, 1992). 
Between 45 and $22 \mathrm{Ma}$, volcanic activity in the Ethiopian plateau (Figs. 1a and b) was characterized by fissural flows. Central volcanoes covered the fissural flows beginning at about $30 \mathrm{Ma}$ and 15-13 Ma, and erupted intermittently into the Pleistocene (Morton et al., 1979; WoldeGabreil et al., 1990; Wolde, 1996; Stewart and Rogers, 1996; Chernet et al., 1998; Pik et al., 1998; Ayalew et al., 2002). Recent geochemical and isotopic studies have focused on the Oligocene-Miocene to Quaternary basic-felsic volcanism that accompanied the formation of the MER. These studies have proposed the involvement of distinct mantle components in various proportions, and the importance of the Afar mantle plume and lithospheric mantle in the sources of the basic lavas (Fig. 1).

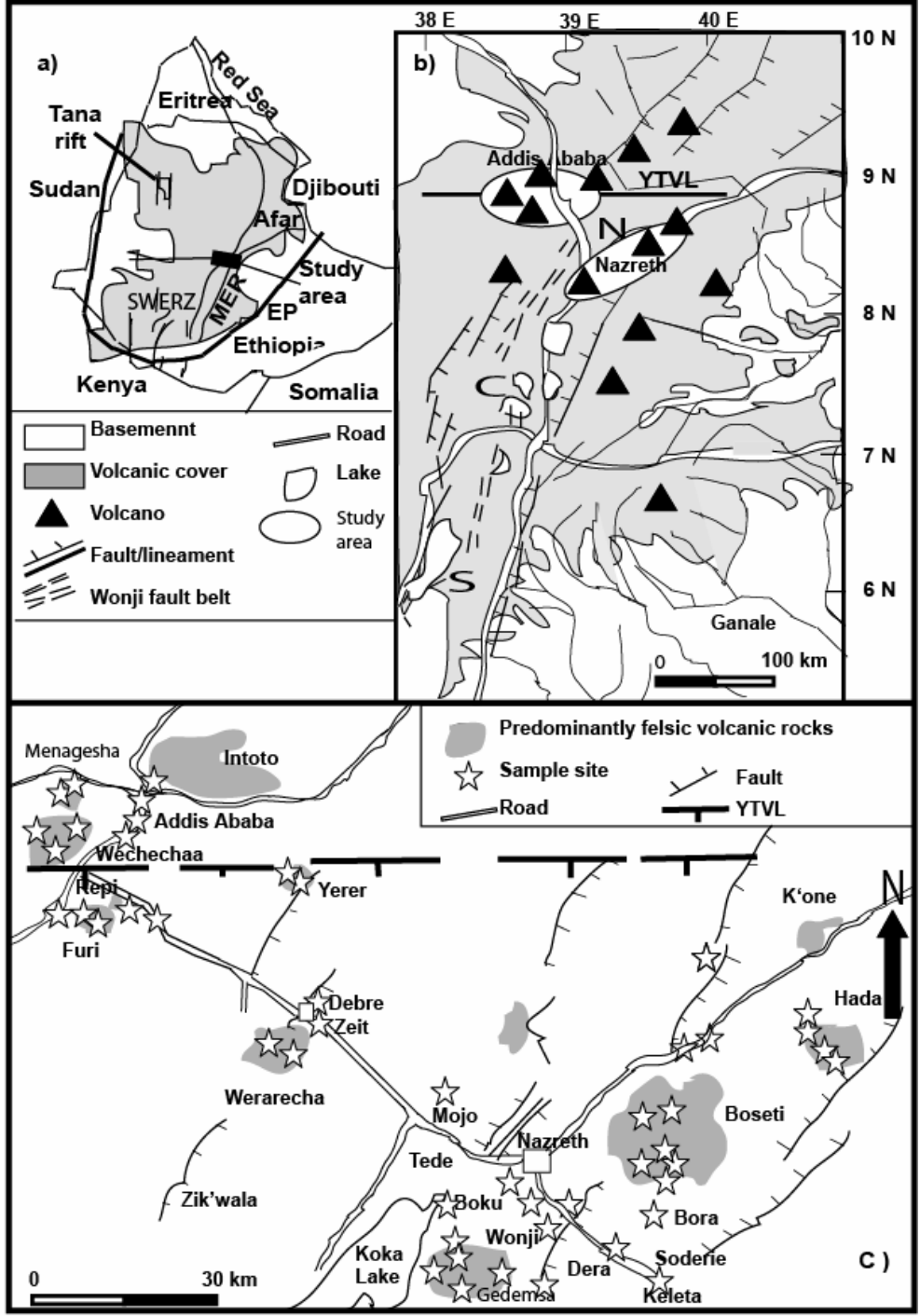

Figure 1. Maps showing the location of the study area. a) Index map showing surface expression of the Ethiopian rift system and volcanic cover (Wolde, 1996) and the Ethiopian Plateau (EP, Stewart and Rogers, 1996). b) Volcanic and tectonic structures of the MER. The white ellipses are the study areas. $\mathrm{N}$ (northern), $\mathrm{C}$ (central), and $\mathrm{S}$ (southern) sectors of the MER; SWERZ is the southwestern Ethiopian Rift Zone. c) Sample sites, felsic volcanic centers and volcanic and tectonic structures of the Addis-Nazreth region. YTVL Yerer Tulu Welel Volcano Tectonic Lineament from Abebe et al. 1998.

Although the previous studies have provided a well-documented framework for the genesis of the basic magmas in MER, the associated felsic magmas are not well studied. Recently, several geochemical and isotopic studies of felsic products have been carried out in the rift center at Debre Zeit, Gedemsa, and Asela-Ziway 
(Fig. 1) (Gasparon et al., 1993; Peccerillo et al., 1995; Trua et al., 1999; Abebe et al., 1998; Boccaletti et al., 1999), on volcanic rocks which are mostly younger than 2 Ma. The felsic volcanic products at the rift margin (Addis Ababa) and rift center (Nazreth) regions and their compositional variations are not yet well studied.

This paper presents new elemental and $\mathrm{Sr}-\mathrm{Nd}$ isotope data for selected volcanic sequences from the northern sector of the MER (Fig. 1). Based on the petrographic, geochemical, and isotopic characteristics of the volcanic units, we describe the compositional differences between the volcanic rocks at the rift margin and rift center, and discuss the petrogenetic relationships between basic and felsic magmas in order to assess the influence of basic parents and continental crust in the genesis of the felsic melts.

\section{GEOLOGICAL SUMMARY OF THE ADDIS ABABA AND NAZRETH REGIONS}

The study area is located in the center of the Ethiopian dome (Fig 1), and contains volcanic sequences that are directly related to the northern Main Ethiopian Rift (MER) activity. Reevaluation of seismic refraction data for the region by Makris and Ginzburg (1987) revealed thinning of the crust from $44 \mathrm{~km}$ thick at Addis Ababa to $30-26 \mathrm{~km}$ in the center of the MER to the east. This led Wolde (1996) to regard the volcanic sequences at Debre Zeit and to its east as rift center, and Miocene to Pliocene volcanic rocks in the Addis Ababa region, west of Debre Zeit as rift margin.

On the basis of whole-rock and mineral K-Ar and ${ }^{40} \mathrm{Ar}-{ }^{39} \mathrm{Ar}$ ages, Morton et al. (1979) and Chernet et al. (1998) found that the volcanic cover extending from Addis Ababa to Nazreth showed age progression from $22.8 \mathrm{Ma}$ in plateau basalts to $0.21 \mathrm{Ma}$ in the rift center volcanic rocks. At the base of the rift margin volcanic rocks, alkaline-transitional basalt (22.8 Ma) of the Plateau unit is in fault contact with the overlying Intoto unit (22.2-22 Ma) (Morton et al. 1979; Chernet et al. 1998). The Intoto unit consists of trachyte-rhyolite flows and associated ignimbrites at its base (22.2 Ma) and plagioclase phyric basalt (22 Ma) in its upper part. The Early Miocene Plateau and Intoto units represent bimodal volcanic rocks, which were formed during a localized terminal episode following the massive Oligocene fissural basalt activity of the northwestern Ethiopian plateau and are present at the rift margin in the Addis Ababa region (Morton et al., 1979; Begazi et al., 1993; Chernet et al., 1998). Because of their close realationship, the Plateau and Intoto units are here collectively referred to as the Plateau unit 
(22.8-22 Ma). The geochemical data for the Plateau unit is not discussed in this paper because they are pre-rifting eruptions.

Volcanic activity resumed at the rift margin after a considerable hiatus between 22-10 Ma, by eruption of transitional-alkaline basalts of the Addis Ababa unit (9-7 Ma). This was followed by the welded trachytic tuffs (5.1 and 3.3 Ma) of the Nazreth unit, which are thought to have been derived from the mostly trachytic Pliocene (4.6-3.09 Ma) Wechecha, Menagesha, Furi, and Yerer volcanoes (Fig. 1). These centers are collectively designated as the Wechecha unit (Chernet et al., 1998).

Predominantly felsic volcanic products were erupted in the Debre Zeit and Nazreth regions in the rift center between 2.0-0.20 Ma. This sequence consists of the Nazreth, Keleta, Boku-Tede, Bofa, Dera-Sodere, Gedemsa, Boseti, and Melkasa units in ascending order (Fig. 1; Boccaletti et al., 1999). For simplicity, the felsic volcanic rocks of Nazreth, Keleta, Boku-Tede, and DeraSodere units are here grouped as the Nazreth unit, whereas the basaltic rocks of the Bofa and Melkasa units are collectively termed the rift center basic volcanic rocks.

\section{CLASSIFICATION AND PETROGRAPHIC SUMMARY}

Most of the samples investigated here were fresh, and collected from lava flows, except for a few welded ignimbrites from the rift center (Table 1). According to the TAS classification diagram (Le Bas et al., 1986) the rock types in both areas range from basalt to rhyolite, but trachytes and rhyolites predominate (Fig. 2). The rocks fall in numerous compositional fields, making terminology cumbersome. Therefore, a restricted set of terms has been adopted here. Rock samples with $\mathrm{SiO}_{2}<53$ wt.\% are defined as basic, whereas samples with $\mathrm{SiO}_{2}>53$ wt.\% are classed as felsic. In common with many bimodal suites in continental rifts and oceanic islands, the basic rocks at the rift margin are generally alkaline or transitional, whereas rift center equivalents are typically transitional (Wolde, 1996) (Fig. 2). Strongly felsic alkaline rocks at the rift margin and center are weakly peralkaline and strongly peralkaline, respectively (Table 1). According to Macdonald (1974), most of the peralkaline felsic volcanic rocks are commendites with rare pantellerites. However, most of the Gedemsa unit samples are pantelleritic (Peccerillo et al., 1995) (not shown in Figure). 
Petrographically, the basic rocks in both rift margin and center are usually aphyric. Porphyritic samples on the other hand are rare and contain about $15-25 \%$ phenocrysts. The phenocryst minerals are olivine, clinopyroxene, and plagioclase with or without opaques. The groundmass of the basic lavas consists of the above phenocryst phases and accessory glass, zircon, apatite, and titanite, along with secondary alteration products including sericite/carbonate, iddingsite, and hematite. Loss on ignition values in these samples differ little from the unaltered samples (Table 1).

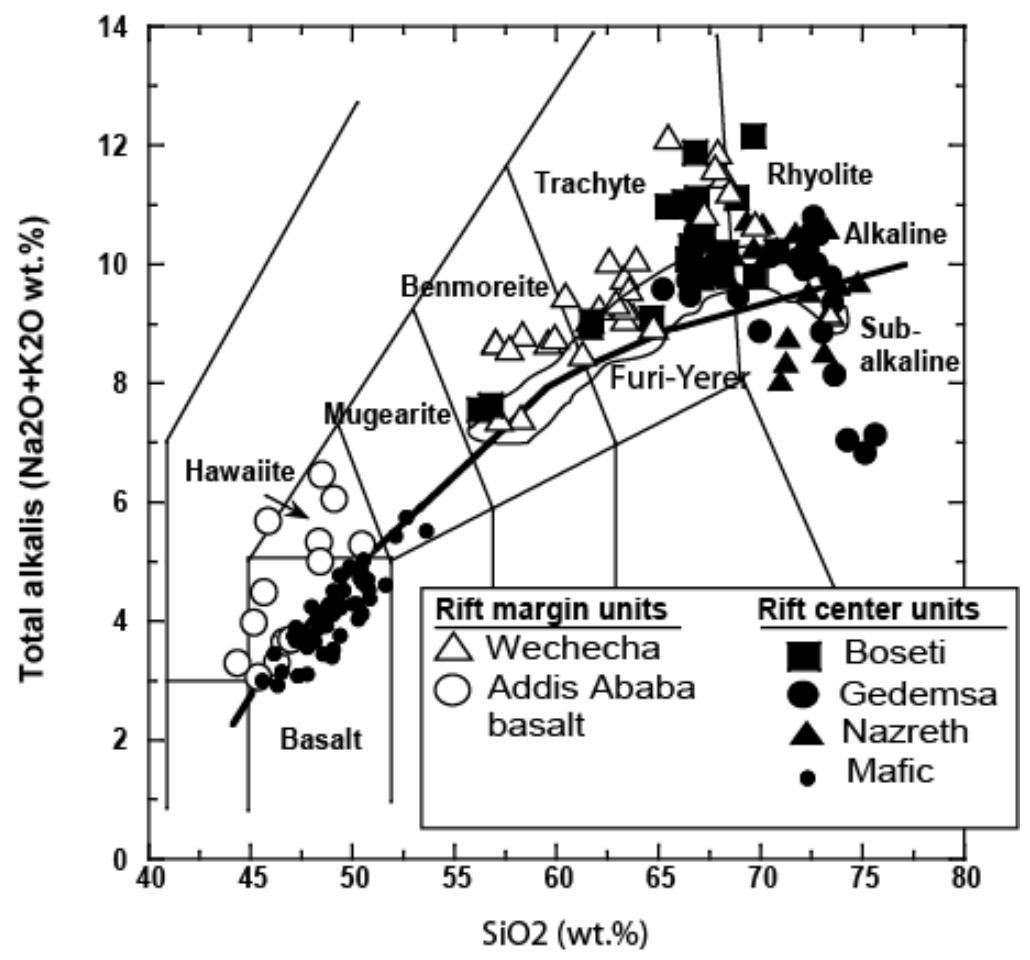

Figure 2. Classification of volcanic rocks of the northern MER according to the scheme of Le Bas et al. (1986). The alkaline-sub-alkaline boundary is from Irvine and Baragar (1971). Additional data for the volcanic rocks from Abebe et al. 1998), Chernet (1995) and Peccerillo et al. (1995).

The felsic volcanic rocks in the rift margin are relatively aphyric compared to the basic rocks, and generally show trachytic textures. The phenocryst minerals $(<15 \%)$ are commonly plagioclase (albiteoligoclase) and anorthoclase, and lesser sanidine, nepheline, alkali amphibole (rebeckite), and aegirine-augite (Chernet, 1995; Abebe et al., 1998). Plagioclase and anorthoclase are the common phenocryst minerals in the rift margin felsic volcanic rocks. Groundmass contains plagioclase, K-feldspars, opaques, augite, and aegirine-augite. Some feldspar grains show melt inclusions along their margins, and rarely amphiboles are altered.

The felsic rift center volcanic rocks contain similar type of minerals as their rift margin equivalents. Majority of the samples are aphyric, but few samples containing up to 35\% phenocryst phases with both felsic and ferromagnesian minerals forming the phenocryst and groundmass phases. Felsic minerals are usually sanidine, quartz, sodic plagioclase, and anorthoclase, whereas the ferromagnesian minerals are aegirine-augite, sodic-amphibole, olivine, 
and opaques. Both the lavas and ignimbrites contain the same minerals, but differ in their textures. The lavas commonly show perlitic cracks/spherulitic groundmass textures, whereas ignimbrites show eutaxitic textures with dominantly vitrophyric fiamme groundmasses.

\section{GEOCHEMISTRY}

\subsection{Analytical Procedures}

Out of 125 collected samples, 75 selected samples from each unit were analyzed for major and trace elements and $\mathrm{Sr}-\mathrm{Nd}$ isotopes (Table 1) in the Department of Geoscience, Shimane University, Japan. Samples were crushed in a tungsten carbide ring mill (Roser et al., 1998), and dried at $110^{\circ} \mathrm{C}$ for 24 hours. No significant $\mathrm{Nb}$ or Ta contamination was present in the carbide ring mill compared to that ground in agate (Roser et al., 1998). The remaining XRF data will be provided upon request. Major and trace element analyses were performed using glass beads prepared either by fusing $0.7 \mathrm{~g}$ of rock powder mixed with $3.5 \mathrm{~g}$ of $\mathrm{Li}_{2} \mathrm{~B}_{4} \mathrm{O}_{7}$ (Norrish and Hutton, $1969)$ or by mixing $1.8 \mathrm{~g}$ sample with $3.6 \mathrm{~g}$ alkali flux $\left(\mathrm{LiBO}_{2}: \mathrm{LiB}_{4} \mathrm{O}_{7}=1: 4\right)$ (Kimura and Yamada, 1996). Analyses were made using a Rigaku RIX 2000 X-ray fluorescence spectrometer, using conventional peak/background methods, with calibration against a suite of Geological Survey of Japan (GSJ) and USGS rock standards. The reproducibility was monitored with appropriate international standards JB01, JB02, and JB03, and was within $\pm 10 \%$ for all elements with concentrations higher than $10 \mathrm{ppm}$.

Sr- and Nd- isotopic measurements and analyses of Sm and $\mathrm{Nd}$ (by isotope dilution) were carried out using Finnigan MAT262 thermal ionization mass spectrometer, following the methods of Iizumi et al. (1994, 1995). Measured ${ }^{87} \mathrm{Sr} /{ }^{86} \mathrm{Sr}$ and ${ }^{143} \mathrm{Nd} /{ }^{144} \mathrm{Nd}$ ratios were normalized to ${ }^{87} \mathrm{Sr} /{ }^{88} \mathrm{Sr}=0.1194$ and ${ }^{146} \mathrm{Nd} /{ }^{144} \mathrm{Nd}=0.7219$. During the analysis of unknowns, measurements of ${ }^{87} \mathrm{Sr} /{ }^{86} \mathrm{Sr}$ and ${ }^{143} \mathrm{Nd} /{ }^{144} \mathrm{Nd}$ in NBS 987 and JMC standard samples were $0.71026 \pm 18(2 \sigma, \mathrm{n}=10)$ and $0.51196 \pm 10(2 \sigma, \mathrm{n}=10)$, respectively (Table.1)

\subsection{Major Element Data}

Whole rock analyses and $\mathrm{Sr}-\mathrm{Nd}$ isotope data of representative samples are listed in Table 1. The remaining data are available upon request. The basic $\left(\mathrm{SiO}_{2}<53\right.$ wt.) rocks have $\mathrm{MgO}$ contents between 4 and 14 wt.\%, Mg-numbers (mg\#) between 50 and 74, $\mathrm{Ni} \leq 380 \mathrm{ppm}$ and $\mathrm{Cr} \leq 822$ ppm. Most of these values suggest that very few rocks represent the primary mantle melts (Sato, 
1977; Wilson, 1989). Majority of the samples having mg\# between 44 and 50 suggest that they do not represent primary magma compositions (Table.1).

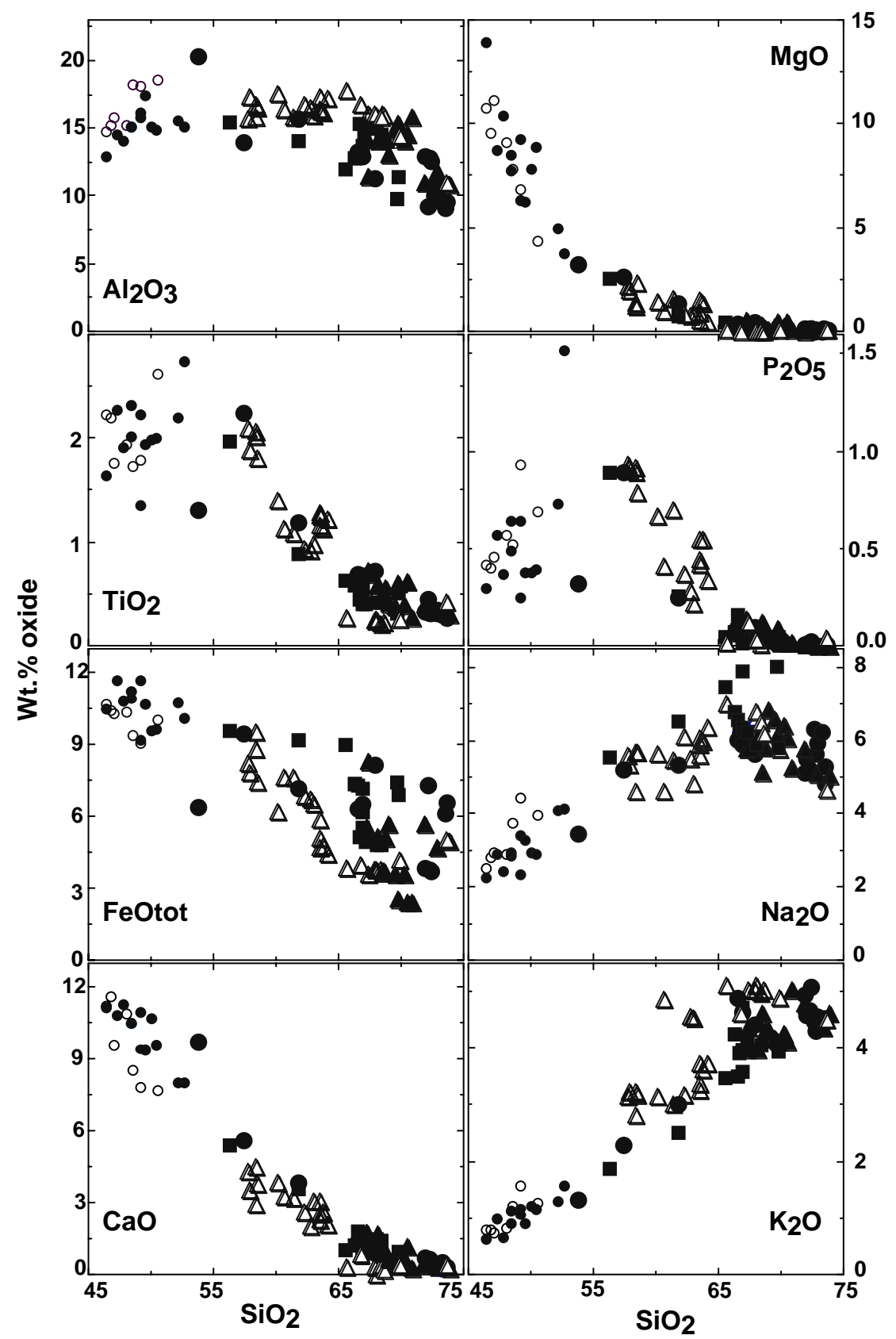

Figure 3. Plots of selected major elements (wt.\%) against differentiation index $\left(\mathrm{SiO}_{2}\right)$ for northern MER volcanic rocks. Symbols as in Fig. 2.

Selected major and trace elements plotted against $\mathrm{SiO}_{2}$ are shown in Figs. 3, 4 and 5. With the exception of two intermediate samples, all the felsic rocks have $\mathrm{SiO}_{2}$ $>57$ wt.\%, and an apparent $\mathrm{SiO}_{2}$ gap (53-57 wt.\%) exists between the basic and felsic volcanic rocks. In all volcanic sequences $\mathrm{MgO}$, $\sum \mathrm{FeO}$ and $\mathrm{CaO}$ generally decrease with increasing $\mathrm{SiO}_{2}$ and $\mathrm{K}_{2} \mathrm{O}$ (Fig. 3). However, $\mathrm{Na}_{2} \mathrm{O}$ contents increase from about 2 wt.\% in the basic volcanic rocks to about 7 wt. $\%$ in the felsic rocks (at $65 \mathrm{wt} \% \mathrm{SiO}_{2}$ ), and then decreases to 4.2 wt.\% increasing $\mathrm{SiO}_{2}(>70 \%)$ in most of the felsic samples. In the Boseti unit, however, $\mathrm{Na}_{2} \mathrm{O}$ continues to increase in some of the felsic rocks. $\mathrm{Al}_{2} \mathrm{O}_{3}$ contents in basic samples range from 13.0 to 21.3 wt.\%, maintain similar values (13.3-17.5 wt.\%) in felsic samples through to 65 wt.\% $\mathrm{SiO}_{2}$, and then decrease to values as low as 9.2 wt.\% at 75 wt.\% 
$\mathrm{SiO}_{2} . \mathrm{P}_{2} \mathrm{O}_{5}$ and $\mathrm{TiO}_{2}$ contents also tend to increase from basic to intermediate compositions (up to 55 wt. $\% \mathrm{SiO}_{2}$ ), and then sharply decrease up to 65 wt.\% $\mathrm{SiO}_{2}$ and remain flat (Fig. 3).

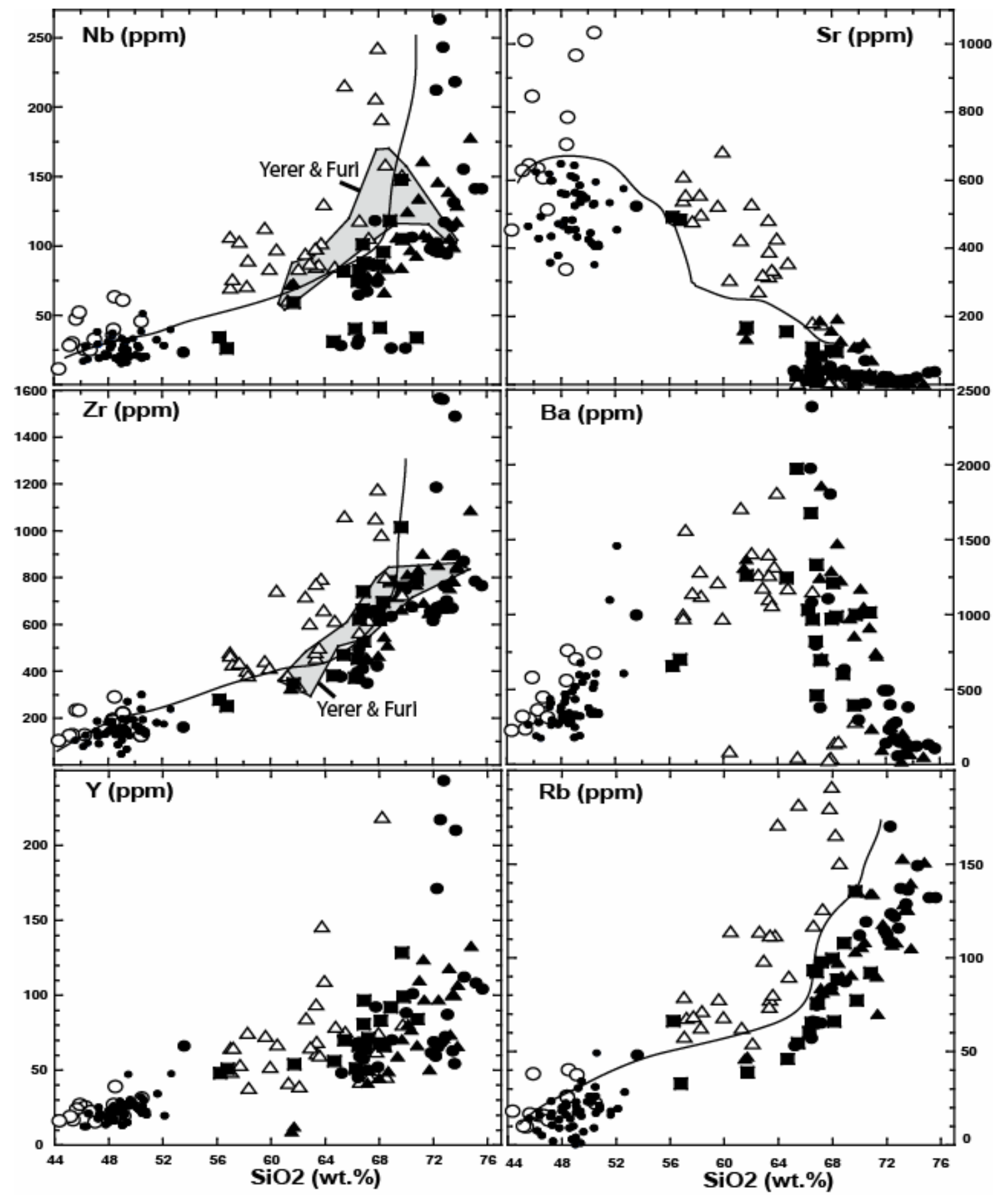

Figure 4. Plots of selected trace elements (ppm) against differentiation index $\left(\mathrm{SiO}_{2} \mathrm{wt} . \%\right)$ for northern MER volcanic rocks. The lines on the $\mathrm{Zr}, \mathrm{Nb}, \mathrm{Sr}$ and $\mathrm{Rb}$ versus $\mathrm{SiO}_{2}$ illustrate the compositional contrasts between the volcanic rocks in the rift center and margins. The shaded area on the $\mathrm{Zr}$ and $\mathrm{Nb}$ plots indicate where samples from the Furi and Yerer Mountains overlap samples from the rift center. Symbols as in Fig. 2. 
Compositional differences exist between the rift margin and rift center volcanic rocks (Table 1; Fig. 3). For example, $\mathrm{CaO}$ contents in the rift center basic rocks (9.4-11.3 wt.\%) are generally higher than most of the rift margin equivalents (7.7-10 wt.\%), except in few clinopyroxenephyric samples from the Addis Ababa unit that are younger (10.9-12.5 wt.\%). In contrast, $\mathrm{Al}_{2} \mathrm{O}_{3}$ contents of most rift margin basic volcanic rocks are higher (14.8-18.6 wt.\%) compared to the rift center equivalents (13-17.5 wt.\%).

The contrasts in $\mathrm{CaO}$ and $\mathrm{Al}_{2} \mathrm{O}_{3}$ seen in the basic lavas of the two regions are also apparent in the felsic volcanic rocks. $\mathrm{Al}_{2} \mathrm{O}_{3}$ contents are greater in most of the felsic rift margin volcanic rocks than in the rift center, whereas $\mathrm{CaO}$ contents are generally greater in the rift center (Fig. 3). $\mathrm{K}_{2} \mathrm{O}$ concentrations are generally greater and $\sum \mathrm{FeO}$ contents lesser in the rift margin felsic volcanic rocks than in the rift center. However, the above compositional differences become less pronounced in samples with $\mathrm{SiO}_{2}$ contents $>67$ wt.\%. Rift center felsic samples are generally richer in $\mathrm{SiO}_{2}$ than most from the Wechecha (Pliocene) unit at the rift margin (Fig. 3)

\subsection{Trace Element Data}

In both the rift margin and rift center volcanic sequences, compatible elements such as $\mathrm{Ni}, \mathrm{Co}$, and $\mathrm{Cr}$ decrease in abundance with increasing $\mathrm{SiO}_{2}$ (Table 1). This indicates the influence of olivine, clinopyroxene, and Fe-Ti oxide fractionation. $\mathrm{Zr}, \mathrm{Nb}, \mathrm{Y}$, and $\mathrm{Rb}$, being incompatible elements show increase in their concentration with fractionation within each rock series, albeit with some scatter (Fig. 4). Sr and Ba contents in the felsic volcanic rocks generally decrease with fractionation, representing compatible behavior, though they too show wide variations.

Most rift margin basic lavas have greater $\mathrm{Zr}$ and $\mathrm{Nb}$ contents than do the rift center basic lavas. Moreover, at given $\mathrm{SiO}_{2}$ content $\mathrm{Sr}$ is much more enriched in rift margin basic lavas than in their rift center equivalents (Fig. 4, Table 1). $\mathrm{Zr}, \mathrm{Nb}, \mathrm{Sr}$, and $\mathrm{Rb}$ are also generally more enriched in their rift margin felsic rocks than in Quaternary rift center felsic equivalents. However, $\mathrm{Y}$ and $\mathrm{Ba}$ abundances mostly overlap, as does $\mathrm{Sr}$ at $>65 \mathrm{wt} . \% \mathrm{SiO}_{2}$. Among the Wechecha felsic samples,

high $\mathrm{Zr}$ and $\mathrm{Nb}$ are observed in the Menagesha and Wechecha mountain samples (Table 1), whereas relatively low $\mathrm{Nb}$ and $\mathrm{Zr}$ contents characterise samples from the Furi and Yerer mountains (Fig. 4).

\subsection{Nd- and Sr- Isotope Data}

Twenty-eight samples spanning the compositional range from the least fractionated $\mathrm{MgO}$-rich rocks to the most fractionated rhyolite samples were analysed for $\mathrm{Sr}-$ and $\mathrm{Nd}$ - isotopes. Isotopic 
ratios as shown in table 1 are plotted in figure 5, together with data for 15 samples from Chernet (1995) and Abebe et al. (1995). Initial ${ }^{143} \mathrm{Nd} /{ }^{144} \mathrm{Nd}$ ratios in the basic lavas range from 0.512812 to 0.51289 , and from 0.51237 to 0.51286 in the felsic volcanic rocks. Initial ${ }^{87} \mathrm{Sr} /{ }^{86} \mathrm{Sr}$ ratios range from 0.70349 to 0.70456 in the basic lavas, and from 0.70446 to 0.70783 in the felsic volcanic rocks. The rift margin basic volcanic rocks have higher Nd- and lower Sr- isotopic ratios than rift center equivalents (Table 1; Fig. 5).

In contrast, felsic volcanic rocks from the rift margin have lower $\mathrm{Nd}$ - isotopic ratios than most of their rift center equivalents. However, their Sr- isotopic compositions are equally variable. The felsic volcanic rocks extend from the isotopic range of the basic volcanic rocks towards higher ${ }^{87} \mathrm{Sr} /{ }^{86} \mathrm{Sr}$ (Fig. 5). Most of the felsic rift center volcanic rocks lie above the Debre Zeit field (Gasparon et al. 1993), whereas the felsic rift margin volcanic rocks partly overlie it. Rift center felsic volcanic rocks overlie the field defined by equally felsic lavas from northern Kenya (Kabeto et al., 2001) (Fig.5).

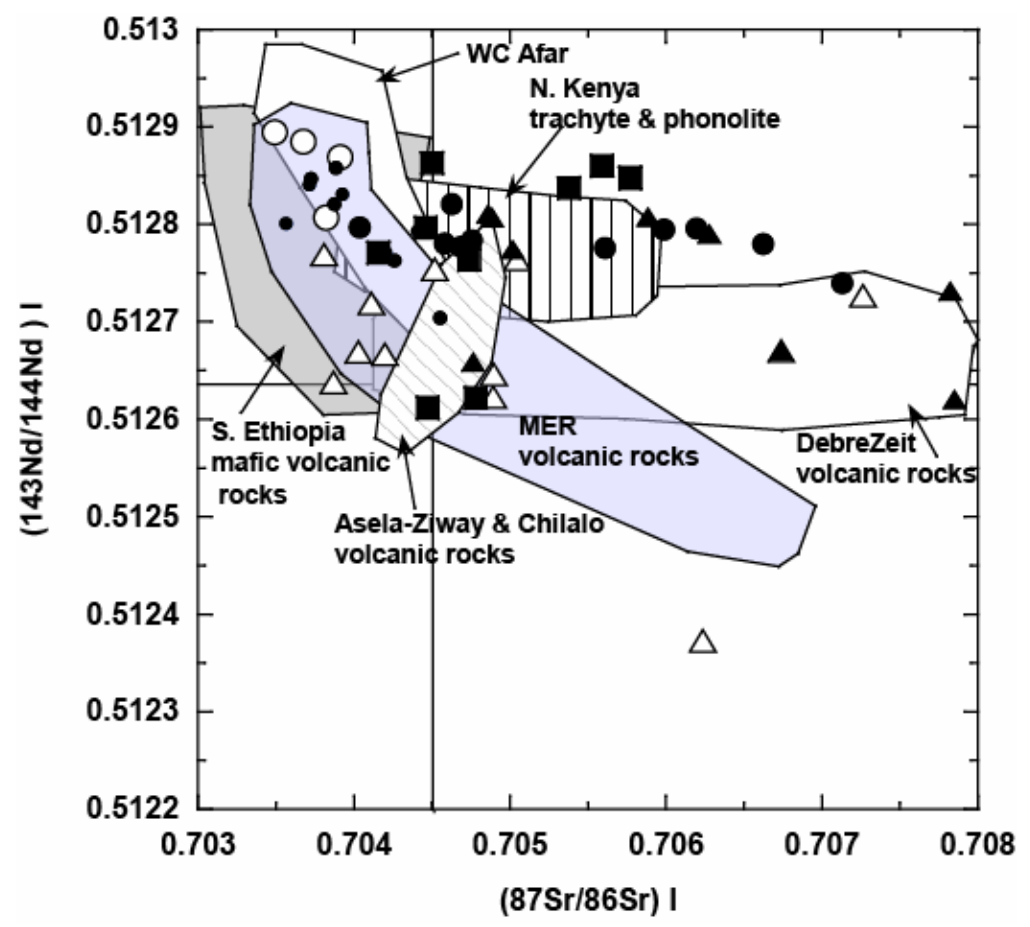

Figure 5. Initial ${ }^{87} \mathrm{Sr} /{ }^{86} \mathrm{Sr}$ and ${ }^{143} \mathrm{Nd} /{ }^{144} \mathrm{Nd}$ ratios for volcanic rocks of the study area, compared to west central (WC) Afar and MER (Hart et al., 1989), Debre Zeit (Gasparon et al., 1993), south Ethiopian (Stewart and Rogers, 1996), Asela-Ziway \& Chilalo (Trua et al., 1999), northern Kenyan volcanic rocks (Kabeto et al., 2001b), and the East African Carbonatite Line (EACL). Measured ${ }^{143} \mathrm{Nd} /{ }^{144} \mathrm{Nd}$ ratio is used for some samples (Table 1). Symbols as in Fig. 2.

\section{DISCUSSION}

It is well established that compositional differences in parental basaltic magmas are reflected in the compositions of felsic melts (Wilson et al., 1995; Panter et al., 1997). Fractional crystallization of basaltic magmas with some crustal assimilation and partial melting of basic 
lower crust/underplated igneous rocks were proposed as dominant processes for generation of felsic melts in the MER rift center (Fig. 1; Gasparon et al., 1993; Abebe et al., 1998; Peccerillo et al., 1995; Trua et al., 1999; Boccaletti et al., 1999). The influence of different parental magma compositions and the processes involved in the genesis of felsic melts in the northern sector of the MER are discussed below.

\subsection{Influence of Parental Magma Compositions}

The general, elemental contrasts between the rift margin and rift center volcanic rocks discussed above (Figs. 3 and 4; Table 1) are clearly evident on $\mathrm{CaO} / \mathrm{Al}_{2} \mathrm{O}_{3}$ vs $\mathrm{SiO}_{2}, \mathrm{Zr}$ vs Nb , and $\mathrm{Zr} / \mathrm{Nb}$ vs $\mathrm{Zr}$ plots (Fig. 6). At a given $\mathrm{SiO}_{2}$ content most of the basic rocks $\left(\mathrm{SiO}_{2}<53\right.$ wt.\%) from the rift center are displaced towards higher $\mathrm{CaO} / \mathrm{Al}_{2} \mathrm{O}_{3}$ ratios (Fig. 6a). Few basic rocks from the rift margin have $\mathrm{CaO} / \mathrm{Al}_{2} \mathrm{O}_{3}$ ratios comparable with rift center equivalents, and in both groups the ratio decreases with fractionation. $\mathrm{CaO} / \mathrm{Al}_{2} \mathrm{O}_{3}$ ratios remain higher in the felsic rift center rocks $\left(\mathrm{SiO}_{2}>53\right.$ wt.\%) than in rift margin equivalents, but a few felsic samples from the Wachecha (Furi and Yerer Mts.) unit overlap (Table 1). This may be due to similar fractionating phases controlling their evolution, or indicate that they were derived from compositionally similar basic parents.

$\mathrm{Zr}$ and $\mathrm{Nb}$ contents show a well defined linear correlation (Fig. 6b), and both being incompatible elements increase with fractionation (Kamber and Collerson, 2000; Kabeto et al., 2001). Constancy of trace element ratios between basic and felsic melts (e.g., $\mathrm{Zr} / \mathrm{Nb}$; Fig. $6 \mathrm{~b}$ and c) is often cited as strong evidence that fractional crystallization has been the dominant process in their evolution (Weaver, 1977; Wilson, 1989). At given Zr content most rift margin samples show higher $\mathrm{Nb}$ contents than do the rift center samples. Kamber and Collerson (2000) have indicated that $\mathrm{Nb}$ is more sensitive to variations in degrees of partial melting than $\mathrm{Zr}$, and hence can be used to decipher the influence of variable degrees of melting. In this regard, some rift margin samples from the Furi and Yerer Mountains have $\mathrm{Nb}$ contents as low as the rift center samples (Table 1; Figs. 4 and 6b). It is evident that Yerer and Furi mountains are compositionally closer to rift center composition than the Wechecha and Menagesha Mountains. Furthermore, samples from Yerer and Furi are younger and have a narrower age range (2.03-4.04 $\mathrm{Ma}$ ) than the Wechacha and Mengasha Mountains samples (3.09-6.63 Ma) (Chernet et al., 1998) (Fig.6). 
Plotting $\mathrm{Zr} / \mathrm{Nb}$ vs $\mathrm{Zr}$ (Fig. 6c) also shows that felsic volcanic rocks of the study area fall into two clusters. Based on their $\mathrm{Zr} / \mathrm{Nb}$ ratios, most samples from the rift margin plot along $\mathrm{Zr} / \mathrm{Nb} \leq 5$, whereas rift center volcanic rocks, and the few samples from the Yerer and Furi Mountains with low $\mathrm{Nb}$ contents cluster along $\mathrm{Zr} / \mathrm{Nb} \geq 6$. Similarly, $\mathrm{Zr} / \mathrm{Nb}$ ratios in the basic rocks of the two sequences also vary (Fig. 6c). The rift center basic rocks have $\mathrm{Zr} / \mathrm{Nb}$ ratio $\geq 5$, whereas most of the basalts from the Addis Ababa area that are thought to be parental to the rift margin felsic volcanic rocks, and a few rift center basic rocks; have $\mathrm{Zr} / \mathrm{Nb} \leq 5$.

$\mathrm{Zr} / \mathrm{Nb}$ ratios in volcanic rocks may also reflect crustal contamination,titanite fractionation or variation in degree of partial melting (Wilson et al., 1995; Kamber and Collerson, 2000; Kabeto et al., 2001). For example, basaltic sample ET1201 from the Plateau unit (Table 1) has a $\mathrm{Zr} / \mathrm{Nb}$ ratio of 13.0. ET1201 has a very low initial $\mathrm{Nd}$ - isotopic ratio $(0.51222 \pm 8)$ compared to other basic lavas with lower $\mathrm{Zr} / \mathrm{Nb}$ ratios, which may indicate that the higher $\mathrm{Zr} / \mathrm{Nb}$ ratio reflects crustal involvement (Kabeto et al. 2001). Hence, we consider the rift center volcanic rocks $(\mathrm{Zr} / \mathrm{Nb}>6)$, and those rift margin volcanic rocks with $\mathrm{Zr} / \mathrm{Nb}$ ratios $>5$, to reflect either crustal input, titanite fractionation (Fig. 6c) or different sources.

The clear differences in crustal thickness, extensional tectonics, age of volcanic activity (Morton et al., 1979; Makris and Ginzburg, 1987; Wolde, 1996; Abebe et al., 1998; Boccaletti et al., 1999), and compositions of volcanic rocks in the two regions suggest that they were derived from different parantal magmas. The role of parental basic magma compositions in the rift margin and center felsic melts must be considered in the light of elevated or depleted absolute trace and major element abundances and the degree of silica saturation. Furthermore, the effects of crustal contamination must be accounted for. For example, the silica saturation in the felsic volcanic rocks in the rift center could be produced by substantial contamination of the basic magma that is parental to most of the Pliocene rift margin eruptives by silica-rich crust. However, this is an unsuitable mechanism to produce the felsic volcanic rocks from the rift center, because open-system behavior would produce higher incompatible trace element abundances in the more contaminated series (DePaolo, 1981; Nelson and Davidson, 1993). This is not observed here. Moreover, the Nd- isotopic compositions of the felsic rift center volcanic rocks lie within the range of basic volcanic rocks in the region (Fig. 5). The lowest Nd- isotopic ratios are noted only in those felsic volcanic rocks at the rift margin that show higher degree of contamination. 

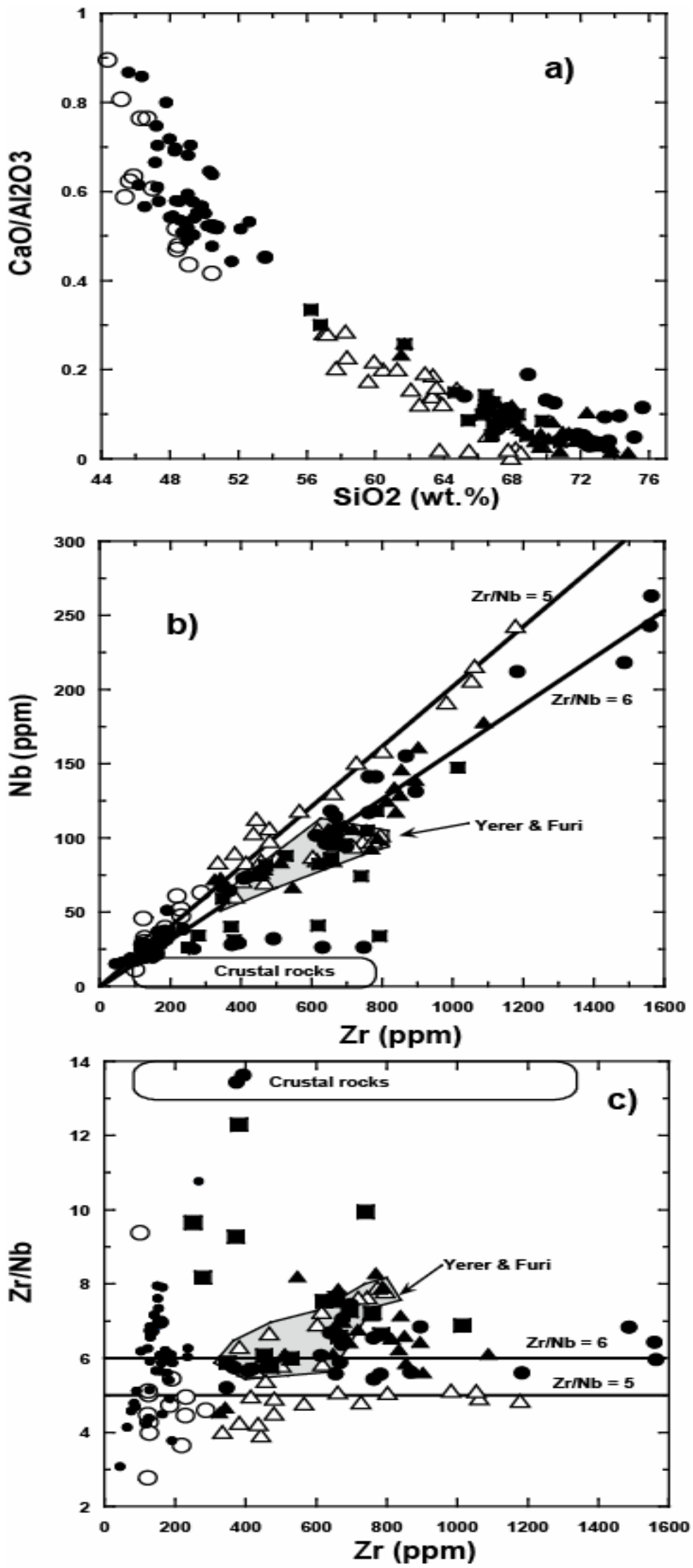

Figure 6. (a) Plot of $\mathrm{CaO} / \mathrm{Al}_{2} \mathrm{O}_{3}$ ratio against $\mathrm{SiO}_{2}$, showing the two apparent evolution trends for the northern MER. Most rift margin volcanic rocks plot at lower ratios. (b) Linear correlation between $\mathrm{Zr}$ and $\mathrm{Nb}$ contents. Samples generally plot along $\mathrm{Zr} / \mathrm{Nb}=5$ and $\mathrm{Zr} / \mathrm{Nb}=7$, which may indicate different sources or crustal input (see text for discussion). (c) $\mathrm{Zr} / \mathrm{Nb}$ vs $\mathrm{Zr}$ plot for the volcanic rocks. Arrows show assumed AFC and differentiation trends (FC) for rift margin and center sequences from different basic parent. The shaded area on (b) and (c) indicate samples from Furi and Yerer Mountains overlapping the samples from the rift center (see text for discussion). Data for crustal rocks from Davidson and Wilson (1989). Symbols as in Fig. 2.

Alternatively, contamination of basic magma, thought to be the parent for rift center felsic products by bulk assimilation of silica deficient crustal material (amphibolitic or basic crust?) must also be considered. This would make the rift margin Wechecha unit magmas more contaminated than rift center felsic magmas (Nelson and Davidson, 1993). We consider this to be unlikely, as it cannot explain the relative depletion of the compatible elements $\mathrm{MgO}$ and $\mathrm{CaO}$ in the Wechecha samples (Fig. 3).

It appears that differing degrees of partial melting of the mantle source 
provide the best explanation for the compositional differences seen between the two volcanic sequences (Nelson and Davidson, 1993). A lower degree of melting, deeper partial melting (Kushiro, 1968; O'Hara, 1968) or melting in the presence of $\mathrm{CO}_{2}$ (Davies and Macdonald, 1987) could easily have produced incompatible element-enriched magma that differentiated to produce the most felsic rift margin samples. In contrast, higher degrees of melting could produce incompatible element depleted magmas that subsequently differentiated to produce the rift center felsic volcanic rocks.

It has been suggested that basic lavas produced by low degrees of mantle partial melting have high incompatible element contents (e.g., $\mathrm{Zr}, \mathrm{Nb}, \mathrm{Y}, \mathrm{K}$, and $\mathrm{Rb}$ ), high $\mathrm{Al}_{2} \mathrm{O}_{3}$, and low $\mathrm{SiO}_{2}$ and $\mathrm{CaO}$ (Tatsumi and Kimura, 1991; Wolde, 1996; Kabeto et al., 2001b). In contrast, basic lavas that are produced by high degrees of partial melting have lower incompatible element and $\mathrm{Al}_{2} \mathrm{O}_{3}$ contents, but higher $\mathrm{CaO}$ and $\mathrm{SiO}_{2}$. Wolde (1996) has shown that alkali basalts produced by a low degree of partial melting are common in the western part of the rift and the margin, and are found only locally east of Debre Zeit (the rift center). In contrast, transitional basalts which originate from higher degrees of partial melting are commonly found within the rift center, where thinning of the crust has been identified from seismic refraction studies (Makris and Ginzburg, 1987). Moreover, Abebe et al. (1995) have suggested that the degree of alkalinity in basaltic melts increases away from the rift center.

In the northern MER, the felsic melts in the rift center generally have lower $\mathrm{Al}_{2} \mathrm{O}_{3}, \mathrm{~K}_{2} \mathrm{O}, \mathrm{Zr}, \mathrm{Nb}$, $\mathrm{Y}, \mathrm{Rb}$, and $\mathrm{Sr}$ and higher $\mathrm{SiO}_{2}$ and $\mathrm{CaO}$ than most rift margin equivalents (Figs. 3 and 4). Hence, the major and trace element contrasts in the felsic products between the two regions could originate from compositional differences in their basaltic parents. Wilson et al. (1995) demonstrated that compositional differences between silica-undersaturated and oversaturated felsic melts in the continental magmatism of the Central Massif (France) were controlled by subtle compositional differences between their respective basic magmas. In line with this suggestion Kabeto et al. (2001) have considered that silica-saturated (basalt-trachyte) and silicaundersaturated (basanite-phonolite) lineages in the northern Kenyan rift sector (Lippard, 1973) originated from compositional differences in their parental basic magmas, and both felsic by differentiation combined with a little assimilation. This is also likely to be the case here. 


\subsection{Fractional Crystallization and/or Degree of Partial Melting}

The general decrease of Ni, $\mathrm{Cr}, \mathrm{Sr}, \mathrm{Ba}, \mathrm{MgO}, \mathrm{CaO}, \Sigma \mathrm{FeO}, \mathrm{TiO}_{2}$, and $\mathrm{P}_{2} \mathrm{O}_{5}$ with increasing $\mathrm{SiO}_{2}$ (Figs. 3 and 4; Table 1) indicates that the geochemical evolution of these volcanic rocks was governed by fractionation of olivine, clinopyroxene, Fe-Ti oxide, feldspars, and apatite. $\mathrm{TiO}_{2}$ and $\mathrm{P}_{2} \mathrm{O}_{5}$ also show to decrease at the same $\mathrm{SiO}_{2}$ content in all rock suites, indicating simultaneous apatite and Fe-Ti oxide fractionation. Moreover, the general increase in $\mathrm{Zr}, \mathrm{Nb}, \mathrm{Rb}$, Y, and $\mathrm{K}$ concentrations with increasing $\mathrm{SiO}_{2}$ is also consistent with fractional crystallization from a similar basic parent, to produce the mugearites, benmoreites, trachytes, and rhyolites of both regions. The well-defined linear correlation between $\mathrm{Zr}$ and $\mathrm{Nb}$ contents in the sequences (Fig. $6 \mathrm{~b}$ and c) also suggests that fractional crystallization was a dominant process.

The Sr- and Nd- isotopic ratios of the felsic lavas (Fig. 5) also do not lie wholly within the isotopic range of their associated basic lavas, indicating that fractional crystallization was not the only process responsible for their genesis.

Genesis of the felsic MER volcanic rocks by anatexis of the upper continental crust must be discarded on the basis of geochemical characteristics. The Afro-Arabian continental crust displays a wide range of isotopic composition (Davidson and Wilson, 1989; Hegner and Pallister, 1989; Möller et al., 1998) which is dissimilar to the felsic MER volcanic rocks (Table 1). The Nd- isotopic compositions of most felsic MER volcanic rocks are also more radiogenic than mean upper crust. Hence, partial melting of the upper continental crust cannot be the source for the felsic melts. Low degrees of partial melting of basic lower crust and/or underplated basic magmas as possible source for the felsic melts can be tested by batch melting modeling calculations (Shaw, 1970; Skjerlie and Johnston, 1993) performed on Rb vs Sr (not shown).

Based on the Sr- isotopic variations between the basic $(0.70349$ to 0.70456$)$ and felsic $(0.70446$ to 0.70783 ) volcanic rocks (Table 1; Fig. 5), it is possible that fractional crystallization might not be the only process responsible for the generation of felsic lavas. Even if the data appears to be explained well by fractional crystallization from a basaltic parent, the fractionation stage could be an open system, and hence some assimilation of crustal material is possible. The estimation of the extent of contamination by crustal material is complicated by the diversity shown by AraboAfrican basement rocks (Hegner and Pallister, 1989; Davidson and Wilson, 1989; Möller et al., 1998). 
The Sr-Nd isotopic compositions of the felsic volcanic rocks from the rift margin also suggest that assimilation of crustal material has occurred may be limited. Initial $\mathrm{Nd}$ - isotopic ratios, which are insensitive to small degrees of contamination, are variable and range from 0.51276 to 0.51237. Hence, we favor fractional crystallization from different basic parents, combined with assimilation of crustal materials, over a combined partial melt and fractionation origin for the felsic volcanic rocks.

\subsection{Assimilation and Fractional Crystallization (AFC)}

A conventional way of identifying crustal contamination in a suite is to show that ${ }^{87} \mathrm{Sr} /{ }^{86} \mathrm{Sr}$ and ${ }^{143} \mathrm{Nd} /{ }^{144} \mathrm{Nd}$ initial ratios vary systematically (increase and/or decrease) with increasing degree of differentiation. Using $\mathrm{SiO}_{2}$ as a fractionation index, most of the felsic rocks here show an overall increase in Sr-isotopic ratio (Fig. 7b). Most intermediate samples from the Wechecha and Boseti units exhibit lower $\mathrm{Nd}$ - isotopic ratios than the highly felsic samples, suggesting higher rates of

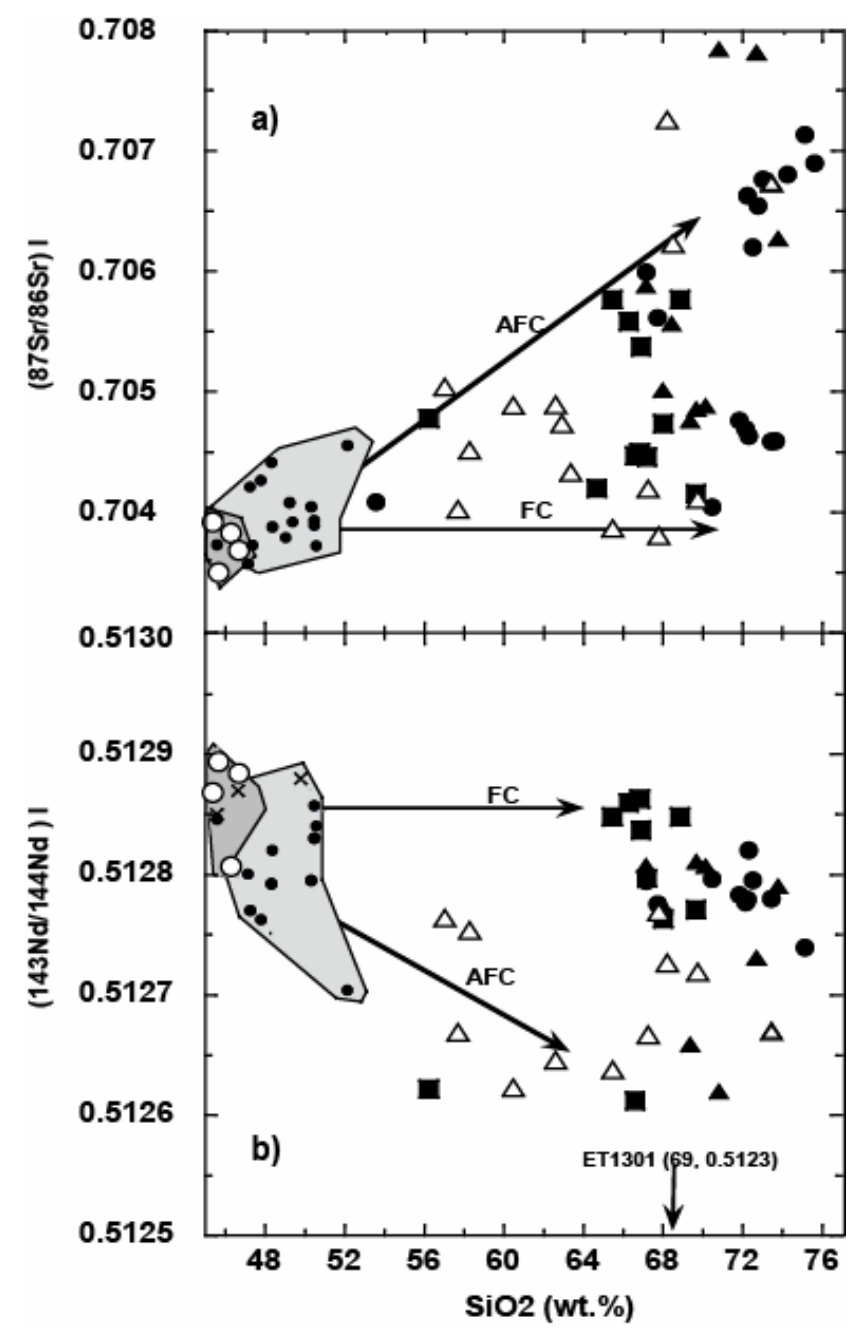

contamination occurred in the intermediate lithotypes (Kabeto et al., 2001). The felsic volcanic samples from the study area apparently plot along AFC trend (Fig. 7a), with some scatter.

Figure 7. Plots of (a) initial Sr- and (b) Ndisotopic ratios against $\mathrm{SiO}_{2}$ for the northern MER volcanic rocks. The felsic rocks plot on two apparent AFC trends. Apparent AFC and differentiation trends (FC) are also shown. The Nd- isotopic ratios also show variations with $\mathrm{SiO}_{2}$ (see text for discussion). Symbols as in Fig. 2.

Few mineral aggregates and resorbed feldspar with melt inclusions were observed during our petrographic investigation. Although this could indicate magma mixing or assimilation, complete mixing can be excluded, because no straight line 
relationships exist on simple binary plots such as $\mathrm{SiO}_{2}-\mathrm{MgO}$ (Fig. 3). Therefore, we consider that magma mixing is a minor process in the genesis of the felsic volcanic rocks.
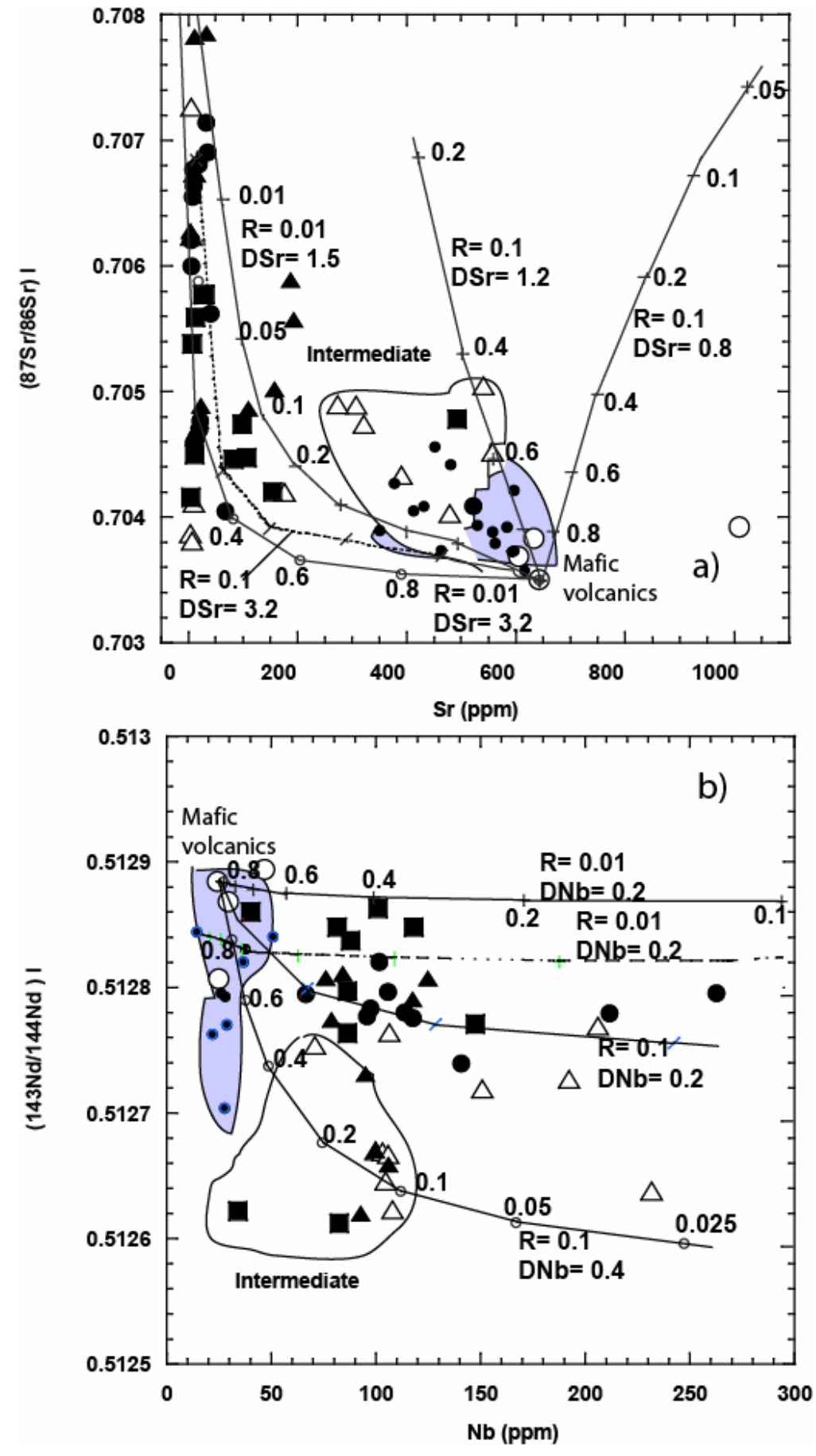

Figure 8. Graphical presentation of the assimilation-fractional crystallization (AFC) model (DePaolo, 1981). (a) Plot of initial ${ }^{87} \mathrm{Sr} /{ }^{86} \mathrm{Sr}$ vs $\mathrm{Sr}$ (ppm), model AFC curves calculated using an average Sudanese upper crust as an assimilant (Davidson and Wilson, 1989; ${ }^{87} \mathrm{Sr} /{ }^{86} \mathrm{Sr}=$ 0.727967, ${ }^{143} \mathrm{Nd} /{ }^{144} \mathrm{Nd}=$ 0.511367, $\mathrm{Sr}=426, \mathrm{Nd}=9.6$, and $\mathrm{Nb}=10 \mathrm{ppm}$ ) and starting basic parent ET1602 (Table 1). Symbols as in Fig. 2.

The elemental and $\mathrm{Sr}-\mathrm{Nd}$ isotopic compositions (e.g., Table 1; Figs. $4,5,6 b, 6 c$, and 7) of the felsic rocks provide evidence of operation of both fractional crystallization and some crustal assimilation (AFC) (DePaolo, 1981). AFC calculations were carried out using sample ET1602 $\left({ }^{143} \mathrm{Nd} /{ }^{144} \mathrm{Nd}=0.512894\right.$, and ${ }^{87} \mathrm{Sr} /{ }^{86} \mathrm{Sr}=0.70350$; Table 1) as starting basaltic compositions and using DePaolo's (1981) equations (Fig. 8). It is assumed that the rock examined was little

modified by crustal contamination, and that crustal influence is of minor importance (isotopically) in the basaltic sample. For example, sample ET1602 has higher ${ }^{143} \mathrm{Nd} /{ }^{144} \mathrm{Nd}$ and lower ${ }^{87} \mathrm{Sr} /{ }^{86} \mathrm{Sr}$ ratios than rhyolite ET1302A, which is most radiogenic $\left({ }^{87} \mathrm{Sr} /{ }^{86} \mathrm{Sr}=0.70727\right.$ and 
${ }^{143} \mathrm{Nd} /{ }^{144} \mathrm{Nd}=0.51273$ ). In addition, the isotopic variability among the basalts is very small (Fig. 5; Table 1) compared to the diversity shown by Arabo-African basement rocks (Cohen et al., 1984; Hegner and Pallister, 1987; Davidson and Wilson, 1989; Halliday et al., 1991; Möller et al., 1998). Hence, the choice of initial compositions is therefore not critical for the AFC calculations (Fig. 8).

Several calculations were made taking $\mathrm{R}$ (assimilation rate/crystallization rate ratio) to be 0.001 , $0.01,0.1,0.3,0.5$, and 0.6. For each model, we assumed $\mathrm{D}_{\mathrm{Sr}}=3.2, \mathrm{D}_{\mathrm{Nb}}=0.3$, and $\mathrm{D}_{\mathrm{Nd}}=0.45$. The D values used are similar to those in the compilation of Rollinson (1995). An example of AFC calculation performed from the average of the Sudanese upper crust (Davidson and Wilson, $1989,{ }^{87} \mathrm{Sr} /{ }^{86} \mathrm{Sr}=0.72797, \mathrm{Sr}=426 \mathrm{ppm}$, and $\left.{ }^{143} \mathrm{Nd} /{ }^{144} \mathrm{Nd}=0.51137, \mathrm{Nb}=9.6, \mathrm{Nd}=24 \mathrm{ppm}\right)$ is shown in Fig. 8a and b, with basalt sample ET1602 taken as the basic parent. Assimilation of the assumed crustal rock by strongly differentiated trachytes and rhyolites at low mass assimilation to mass crystallization rates $(\mathrm{R}=0.001-0.6)$, and moderate to high $\mathrm{F}$ values $(>0.1$ on $\mathrm{AFC}$ curves) can produce the samples which exhibit high ${ }^{87} \mathrm{Sr} /{ }^{86} \mathrm{Sr}$, low $\mathrm{Sr}(<185 \mathrm{ppm})$, low ${ }^{143} \mathrm{Nd} /{ }^{144} \mathrm{Nd}$ and high $\mathrm{Nb}(>200 \mathrm{ppm})$.

${ }^{87} \mathrm{Sr} /{ }^{87} \mathrm{Sr}$ ratios plotted against Sr concentration (Fig. 8a) clearly show the effects of AFC. The data describes a curved differentiation trend with a sharp inflection around the highly felsic compositions, reflecting the strong influence of plagioclase fractionation with concomitant decrease in Sr (Figs. 4 and 8). The hypothetical trend describes the general differentiation trend among the felsic rocks, along which $\mathrm{Ni}, \mathrm{Cr}, \mathrm{CaO}$, and $\mathrm{MgO}$ contents broadly decrease. Such hypothetical curves were also tested in the Jebel Marra area of the Sudan (Davidson and Wilson, 1989) and were successfully applied to northern Kenyan felsic lavas (Kabeto et al., 2001), to examine the evolution of basaltic to trachytic and phonolitic magmas.

Relatively higher rates of assimilation are calculated for intermediate rocks (Fig. 8a and b). This may be explained by differentiation of intermediate magmas at deeper levels in the crust, where higher ambient wallrock temperatures and presence of hot basic magmas would facilitate higher rates of assimilation (Davidson and Wilson, 1989; Macdonald et al., 1995; Panter et al., 1997). Furthermore, high rates of assimilation (0.3-0.6) are evident for most felsic volcanic rocks from the rift margin (Fig. 8b), indicating a greater degree of contamination than at the rift center. This is also in agreement with the thicker crust at the rift margin than at the rift center (Makris and Ginzburg, 1987). 


\section{CONCLUSIONS}

Studies of the northern Main Ethiopian Rift (MER) volcanic rocks offer insight into the genetic relations of basic and felsic volcanic rocks, and establish that compositional contrasts occur in equivalent volcanic rocks at rift margin and center magma series within a single intraplate continental setting. Higher $\mathrm{Al}_{2} \mathrm{O}_{3}, \mathrm{~K}_{2} \mathrm{O}, \mathrm{Zr}, \mathrm{Nb}, \mathrm{Sr}$, and $\mathrm{Rb}$ and lower $\mathrm{CaO}, \mathrm{CaO} / \mathrm{Al}_{2} \mathrm{O}_{3}$, and $\mathrm{Zr} / \mathrm{Nb}$ concentrations in the rift margin felsic volcanic rocks erupted mostly in the Pliocene compared to the Quaternary equivalents in the rift center reflect inheritance from their basic parents. The spatial and temporal distinctions between the volcanic suites in the study area and their markedly different geochemistry are explained by evolution along separate magma trends. Hence, alkaline basaltic melts produced by lower degrees of partial melting are a possible source for most of the felsic volcanic rocks at the rift margin. In contrast, transitional basaltic melts produced at high degrees of partial melting are thought to be the parent for the felsic volcanic rocks in the rift center.

Modeling of the geochemical variations suggests that crystal-liquid fractionation processes within the shallow reservoirs were dominant during most trachyte-rhyolitic production in the rift center, along with less well-developed AFC processes. AFC appears to play a greater role in the genesis of intermediate rift center rocks and felsic rocks at the rift margin. We consider this to partly be a function of depth of fractionation of the magmas, implying that intermediate and rift margin magmas differentiated at deeper levels, whereas the more felsic trachytes and rhyolites of the rift center originated at shallow crustal levels. This is also in agreement with known variation in crustal thickness, variation as thinner crust is present in the rift center than at the rift margin.

\section{ACKNOWLEDGMENTS}

We thank Prof. S. Iizumi for his help with isotope analyses and Dr. T. Bary for AFC model calculation and discussion. K. Kabeto acknowledges financial support from Japan Society for Promotion of Science (JSPS) during post doctoral research at Shimane University. Thanks are also due to Prof. K. Koeberl, Dr. D. Kuester and Dr. K. Bheemalingeswara for providing critical comments and constructive suggestions that have undoubtedly improved the quality of the paper.

\section{REFERENCES}

Abebe, T., Mazzarini, F., Innocenti, F. \& Manetti, P. 1998. The Yerer-Tullu Wellel volcanotectonic lineament: a transtensional structure in central Ethiopia and the associated magmatic activity. J. Afr. Earth Sci., 26:135-150. 
Abebe, T. 1995. L'allineamento vulcano-tettonica Yerer-Tullu Wellel (Etiopia centrale): evoluzione petrologica e volcanologica di un sistema transversale al rift etiopico. $\mathrm{PhD}$ thesis University of Florence, Dipartimento di Scienze della Terra, (unpubl.).

Ayalew D., Barrey, P., Marty, B., Reisberg, L., Yirgu, G. \& Pik. R. 2002. Source, genesis, and timing of giant ignimbrite deposits associated with Ethiopian continental flood basalts Geochemica et Cosmochimica Acta, 66: 1429-1448.

Boccaletti, M., Mazzuoli, R., Bonini, M., Tura, T. \& Abebe, B. 1999. Plio-Quaternary volcanotectonic activity in the northern sector of the Main Ethiopian Rift: relationships with oblique rifting, J. Afr Earth Sci., 29: 679-698.

Bigazzi, B., Bonadonna, F.P., DiPaola, G.M. \& Giuliani, A. 1993. K-Ar and fission track ages of the last volcano tectonic phase in the Ethiopian Rift Valley (Tullu Moye area). In: Geology and mineral resources of Somalia and surrounding regions. Ist. Argon. Oltremare, Firenze, Relaz. E Monogr., 113: 311-322.

Chernet, T., Hart, W.K., Arson, J.L. \& Walter R.C. 1998. New age constraints on the timing of volcanism and tectonism in the northern Main Ethiopian Rift-southern Afar Transition zone (Ethiopia) Journal of Volcanological and Geothermal Research, 80: 267-280.

Chernet, T. 1995. Petrological, Geochemical and Geochemical and Geological Investigation of volcanism in the northern Main Ethiopian Rift-Southern Afar Transition Region. PhD thesis, University of Miami, Oxford, Ohio, (unpubl.).

Cohen, R.W. S., O’Nions, R. K. \& Dawson, J. B. 1984. Isotope geochemistry of xenoliths from East Africa: Implications for the development of mantle reservoirs and their interactions. Earth Planet. Sci. Lett., 68: 209-220.

Davidson, J.P. \& Wilson, I.R. 1989. Evolution of an alkali basalt-trachyte suite from Jebel Marra volcano, Sudan, through assimilation and fractional crystallization. Earth Planet. Sci. Lett., 95: 141-160.

Davies, G.R. \& Macdonald, R. 1987. Crustal Influences in the petrogenesis of the Naivasha Complex: Combined Trace Element and Sr-Nd-Pb Isotope constraints. J. Petrol., 28: 1009-1031.

DePaolo, D. J. 1981. Trace element and isotopic effects of combined wallrock assimilation and fractional crystallization. Earth Planet. Sci. Lett., 53: 189-202. 
Gasparon, M., Innocenti, F., Manetti, M., Peccerillo, P. \& Abebe, T. 1993. Genesis of the liocene to Recent bimodal mafic-felsic volcanism in Debre Zeit area, central Ethiopia: volcanological and geochemical constraints. J. Afr. Earth Sci., 17: 145-165.

Halliday, A.N., Davidson, J.P., Hildreth, W. \& Holden, P. 1991. Modeling the petrogenesis of high $\mathrm{Rb} / \mathrm{Sr}$ silicic magmas. Chem. Geol., 92: 107-114.

Hart, W.K., WoldeGabriel.G., Walter, R.C. \& Mertzman, S.A. 1989. Basaltic volcanism in Ethiopia. Constraints on continental rifting and mantle interactions. J. Geophys. Res., 94: 7731-7748.

Hegner, E. \& Pallister, J.S. 1989. Lead, strontium and neodymium isotopic characteristics of Tertiary Red Sea rift volcanics from the central Saudi Arabian coastal plain. J. Geophys. Res., 94: 7749-7755.

Iizumi, S., Maehara, K., Morris, P. \& Sawada, Y. 1994. Sr isotope data of GSJ reference samples. Mem. Fac. Sci., Shimane Univ., 28 : 83-86.

Iizumi, S., Morris, P. \& Sawada, Y. 1995. Nd isotope data of GSJ reference samples. Mem. Fac. Sci., Shimane Univ., 29: 73-76.

Irvine, T.N. \& Baragar, W. R. A. 1971. A guide to the chemical classification of the common volcanic rocks. Canadian Journal Earth Sciences, 8: 523-548.

Kabeto, K., Sawada, Y. \& Wakatsuki, T. 2001. Different Evolution trends in Alkaline evolved lavas from the Northern Kenyan Rift. J. Afr. Earth Sci., 3: 419-433.

Kamber, B.S. \& Collerson, K.D. 2000. Zr/Nb Systematics of Ocean Island Basalts Reassessedthe Case for Binary Mixing. J. Petrol., 41: 1007-1021.

Kimura, J. \& Yamada, Y. 1996. Evaluation of major and trace element XRF analyses using a flux to sample ratio of two to one glass beads. J. Min. Petr. Econ. Geol., 91: 62-72.

Kushiro, I. 1968. Compositions of magma formed by partial zone melting of the Earth's upper mantle. J. Geophys. Res., 73 : 619-634.

Le Bas, M. J., LeMaitre, R. W., Streckeisen, A. \& Zanettin, B. 1986. A chemical classification volcanic rocks based on the total alkali-SiO${ }_{2}$ diagram. J. Petrol., 27: 45-750.

Lippard, S.J. 1973. The petrology of phonolites from the Kenyan rift. Lithos, 6: 217-34.

Macdonald, R. 1974. Nomenclature and petrochemistry of the peralkaline oversaturated extrusive rocks. Bull. Volcanology, 35: 78-83. 
Macdonald, R. Davies, G.R., Upton, B.G. J., Dunkley, P.N., Smith, M. \& Leat, P.T. 1995. Petrogenesis of Silali volcano, Gregory Rift, Kenya. J. Geol. Soc. London, 152: 703-720.

Makris, J. \& Ginzburg, A. 1987. The Afar depression: transition between continental rifting and sea-floor spreading. Tectonophysics, 141: 199-214.

Mohr, P. 1992. Nature of the crust beneath magmatically active continental rifts. Tectonophysics, 213: 269-284.

Möller, A., Mezger, K. \& Schenk, V. 1998. Crustal Age Domains and the Evolution of the Continental Crust in the Mozambique Belt of Tanzania: Combined Sm-Nd, Rb-Sr, and $\mathrm{Pb}-\mathrm{Pb}$ Isotopic Evidence. J. Petrol., 39: 749-783.

Morton, W.H., Rex, D.C., Mitchell, J.G. \& Mohr, P. 1979. Rift-ward younging of volcanic units in the Addis Ababa region. Ethiopian rift valley. Nature, 280: 284-288.

Nelson, S. \& Davidson, J.P. 1993. Intractions Between Mantle-Derived Magmas and mafic Crust, Henry Mountains, Utah. J. Geophys. Res., 98: 1837-1852.

Norrish, K. \& Hutton, J.T. 1969. An accurate X-ray spectrographic method for the analysis of a wide range of geochemical samples. Gochem. et Cosmochem. Acta, 33: 431-453.

O'Hara, M.H. 1968. The bearing of phase equilibria studies in synthetic and natural systems on the origin and evolution of basic and ultrabasic rocks, Ann. Rev. Earth Planet. Sci. lett., 4: 69-133.

Panter, S. K., Philip, R. K. \& John, L. S. 1997. Petrogenesis of a Phonolite-Trachyte Succession at Mount Sidley, Marie Byrd Land, Antarctica. J. Petrol., 38: 1225-1253.

Peccerillo, A., Yirgu, G. \& Ayalew, D. 1995. Genesis of Acid volcanics along The Main Ethiopian Rift: Case history of the Gedemsa Volcano. SINET, Ethiop. J. Sci., 18: 23-50.

Pik. R., Daneil C., Yirgu, G., Hofmann, C. \& Ayalew D. 1998. The northwestern Ethiopian flood basalts: Classification and spatial distribution of magma types Journal of Volcanological and Geothermal Research, 81: 91-111.

Rollinson, H. R. 1995. Using Geochemical Data: evaluation, presentation and interpretation. Longman, London, $352 \mathrm{pp}$.

Roser, B.P., Sawada, Y. \& Kabeto, K. 1998. Crushing performance and contamination trials of a tungsten carbide ring mill compared to agate grinding. Geosci. Rept. Shimane Univ., $17: 1-9$. 
Sato, H. 1977. Nickel content of basalt magmas; identification of primary magmas and a measure of the degree of olivine fractionation. Lithos, 10: 113-120.

Shaw, D.M. 1970. Trace element fractionation during anatexis. Gochem. et Cosmochem. Acta, 34: $237-243$.

Skjerlie, K.P. \& Johnston, D. 1993. Fluid absent melting behavior of F-rich tonolitic gneisses. J. Petrol., 34: 785-803.

Stewart, K. \& Rogers, N.W. 1996. Mantle plume and lithosphere contributions to basalts from southern Ethiopia. Earth Planet. Sci. Lett., 139: 195-211.

Tatsumi, Y. \& Kimura, N. 1991. Secular variation of basalt chemistry in the Kenya Rift: evidence for the pulsing of asthenospheric upwelling. Earth Planet. Sci. Lett., 104: 99113.

Trua, T., Deniel, C. \& Mazzuoli, R. 1999. Crustal control in the genesis of Plio-Quaternary Bimodal magmatism of the Main Ethiopian Rift (MER): geochemical and isotopic (Sr, $\mathrm{Nd}, \mathrm{Pb}$ ) evidence. Chem. Geol., 155: 201-231.

Weaver, S. D. 1977. The Quaternary Caldera Volcano Emuruangogolak, Kenya Rift, and the Petrology of a Bimodal Ferrobasalt-Pantelleritic-Trachyte Association. Bull. Volcanology, 40: 209-230.

Wilson, M. 1989. Igneous Petrogenesis. Unwin Hyman, London, 466 pp.

Wilson, M., Downes, H. \& Cebriá, J. 1995. Contrasting fractionation trends in coexisting continental alkaline magma series; Cantal, Massif Central, France. J. Petrol., 36: 17291753.

Wolde, B. 1996. Spatial and temporal variations in the compositions of Upper Miocene to Recent basic lavas in the northern main Ethiopian rift: implications for the causes of Cenozoic magmatism in Ethiopia. Geol. Rundsch, 85: 380-389.

WoldeGabreil, G., Aronson, J.L. \& Walter, R.C. 1990. Geology, geochronology and rift basin development in the central sector of the Main Ethiopian Rift. Geol. Soc. Bull., 102: 439458. 
Table 1. Chemical and Sr-Nd isotopic compositions of selected samples from the northern MER. Abbreviations are: nd $=$ not detected; $-=$ not measured; $\mathrm{M}=$ Measured ratio; $\mathrm{I}=$ initial ratio, Tra $=$ trachyte, rhy $=$ rhyolite, benm = benmoreite, ha $=$ hawaite, ba $=$ basalt, igni $=$ ignimbrite, and $\mathrm{obs} / \mathrm{pst}=\mathrm{obsidian} /$ pitchstone. Major oxides in wt.\% and trace elements in ppm. Major and trace element oxides are recalculated to $100 \%$ on an hydrous basis. Ages from Morton et al. (1979) and Boccaleti et al. (1999).

\begin{tabular}{|c|c|c|c|c|c|c|c|c|c|c|c|c|c|c|}
\hline UNIT & Nazreth & & & & & & Boseti & & & & & & & \\
\hline Sample No. & ET14 & $\begin{array}{c}\text { ET } \\
971602 \\
\end{array}$ & $\begin{array}{r}\text { ET } \\
117 \\
\end{array}$ & ET1607 & ET1608 & $\begin{array}{c}\text { ET } \\
1702 \mathrm{~A} \\
\end{array}$ & ET1504 & ET1507 & ET1505 & ET1501 & ET1506 & ET1605 & ET1604b & ET1603b \\
\hline Locality & Tafu & Kone & Barko & Harbona & Kimbo & Boku & Boseti & Boseti & Boseti & Wolenchiti & Boseti & Hada & Hada & Hada \\
\hline Rock type & trachyte & rhyolite & rhyolite & rhyolite & rhyolite & rhyolite & benmoreite & trachyte & trachyte & trachyte & rhyolite & trachyte & rhyolite & rhyolite \\
\hline Age (Ma) & 0.6 & 0.3 & 0.5 & 0.6 & 0.83 & 0.5 & 0.5 & 0.5 & 0.5 & 0.5 & 0.5 & 0.5 & 0.5 & 0.5 \\
\hline $\mathrm{SiO}_{2}$ & 67.98 & 68.84 & 71.72 & 69.35 & 69.67 & 73.78 & 56.24 & 65.44 & 66.82 & 66.90 & 69.66 & 66.61 & 67.19 & 68.00 \\
\hline $\mathrm{TiO}_{2}$ & 0.59 & 0.41 & 0.40 & 0.38 & 0.61 & 0.31 & 2.13 & 0.63 & 0.41 & 0.47 & 0.32 & 0.45 & 0.41 & 0.41 \\
\hline $\mathrm{Al}_{2} \mathrm{O}_{3}$ & 14.07 & 13.02 & 11.00 & 14.94 & 15.35 & 10.85 & 15.38 & 12.07 & 13.71 & 14.50 & 9.84 & 15.42 & 15.18 & 15.04 \\
\hline $\mathrm{Fe}_{2} \mathrm{O}_{3}$ & 0.85 & 0.93 & 0.92 & 0.59 & 0.42 & 0.82 & 1.52 & 1.48 & 1.02 & 0.91 & 1.22 & 0.84 & 0.82 & 0.80 \\
\hline $\mathrm{FeO}$ & 4.34 & 4.73 & 4.74 & 2.99 & 2.14 & 4.16 & 8.33 & 7.54 & 5.20 & 4.66 & 6.24 & 4.30 & 4.17 & 4.06 \\
\hline $\mathrm{MnO}$ & 0.21 & 0.19 & 0.21 & 0.16 & 0.15 & 0.15 & 0.31 & 0.30 & 0.22 & 0.23 & 0.26 & 0.16 & 0.16 & 0.16 \\
\hline $\mathrm{MgO}$ & 0.32 & 0.06 & 0.03 & 0.22 & 0.44 & 0.02 & 2.60 & 0.48 & 0.01 & 0.09 & - & 0.22 & 0.14 & 0.13 \\
\hline $\mathrm{CaO}$ & 1.68 & 0.67 & 0.44 & 0.58 & 0.85 & 0.27 & 5.14 & 1.04 & 0.72 & 1.10 & 0.29 & 1.64 & 1.48 & 1.47 \\
\hline $\mathrm{Na}_{2} \mathrm{O}$ & 5.86 & 6.82 & 5.77 & 6.57 & 6.16 & 5.02 & 5.56 & 7.49 & 7.89 & 6.38 & 8.04 & 6.38 & 6.22 & 5.90 \\
\hline $\mathrm{K}_{2} \mathrm{O}$ & 3.99 & 4.30 & 4.77 & 4.17 & 4.12 & 4.62 & 1.99 & 3.47 & 3.98 & 4.72 & 4.12 & 3.92 & 4.20 & 3.99 \\
\hline $\mathrm{P}_{2} \mathrm{O}_{5}$ & 0.09 & 0.03 & 0.01 & 0.04 & 0.09 & - & 0.80 & 0.05 & 0.02 & 0.03 & 0.01 & 0.06 & 0.04 & 0.04 \\
\hline LOI & 1.47 & - & - & 1.48 & 2.10 & 0.20 & 0.20 & 2.45 & 0.29 & 1.07 & 0.73 & 1.08 & 1.98 & 0.45 \\
\hline Alkali total & 9.85 & 11.12 & 10.53 & 10.74 & 10.28 & 9.64 & 7.55 & 10.96 & 11.87 & 11.10 & 12.16 & 10.29 & 10.42 & 9.89 \\
\hline Agpaitic index & 0.99 & 1.22 & 1.33 & 1.03 & 0.95 & 1.22 & 0.73 & 1.33 & 1.26 & 1.08 & 1.80 & 0.96 & 0.97 & 0.93 \\
\hline Mg number & 11.75 & 2.08 & 1.05 & 11.70 & 26.95 & 1.04 & 35.76 & 10.22 & 0.47 & 3.23 & - & 8.47 & 5.64 & 5.36 \\
\hline
\end{tabular}




\section{(Continued)}

\begin{tabular}{|c|c|c|c|c|c|c|c|c|c|c|c|c|c|}
\hline UNIT & Plateau & Addis Ababa & & & Wechecha & & & & & & Rift cent & r mafic & \\
\hline Sample No. & ET1201 & ET1303 & ET1602 & ET1403 & ET1203B & ET1405 & ET1404A & ET1203A & ET1302 & ET1301 & ET1606 & ET1508 & ET1507b \\
\hline Locality & Intoto & Wechecha & Addis & Akaki & Menagesha & Yerer & Yerer & Menagesha & Wechecha & Wechecha & Wonji & Sodorei & Boku \\
\hline Rock type & basalt & basalt & basalt & basalt & benmoreite & benmoreite & benmoreite & trachyte & trachyte & rhyolite & basalt & basalt & hawaiite \\
\hline Age (Ma) & 22.8 & 7.5 & 7 & 7 & 4 & 3.09 & 3.09 & 3.6 & 4 & 4.6 & 0.5 & 0.5 & 0.5 \\
\hline $\mathrm{SiO}_{2}$ & 47.20 & 46.32 & 45.69 & 46.71 & 57.02 & 60.46 & 62.59 & 65.47 & 68.20 & 68.50 & 47.81 & 48.33 & 52.16 \\
\hline $\mathrm{TiO}_{2}$ & 1.72 & 2.24 & 2.63 & 2.21 & 2.08 & 1.14 & 0.92 & 0.27 & 0.21 & 0.22 & 1.92 & 2.32 & 2.20 \\
\hline $\mathrm{Al}_{2} \mathrm{O}_{3}$ & 21.17 & 14.75 & 15.52 & 15.21 & 15.48 & 16.44 & 16.53 & 17.79 & 15.85 & 16.00 & 14.12 & 15.14 & 15.56 \\
\hline $\mathrm{Fe}_{2} \mathrm{O}_{3}$ & 1.55 & 1.76 & 1.89 & 1.72 & 1.39 & 1.26 & 1.10 & 0.63 & 0.62 & 0.61 & 1.77 & 1.85 & 1.76 \\
\hline $\mathrm{FeO}$ & 7.93 & 8.97 & 9.65 & 8.76 & 7.50 & 6.41 & 5.63 & 3.20 & 3.17 & 3.10 & 9.04 & 9.42 & 8.99 \\
\hline $\mathrm{MnO}$ & 0.14 & 0.18 & 0.16 & 0.17 & 0.33 & 0.13 & 0.13 & 0.11 & 0.08 & 0.07 & 0.17 & 0.17 & 0.21 \\
\hline $\mathrm{MgO}$ & 4.24 & 10.81 & 9.77 & 9.57 & 2.19 & 0.98 & 0.75 & 0.06 & 0.02 & 0.01 & 10.42 & 7.73 & 4.94 \\
\hline $\mathrm{CaO}$ & 12.51 & 11.26 & 9.66 & 11.62 & 4.37 & 3.30 & 2.01 & 0.31 & 0.36 & 0.22 & 11.29 & 10.55 & 8.02 \\
\hline $\mathrm{Na}_{2} \mathrm{O}$ & 2.67 & 2.50 & 3.41 & 2.84 & 5.55 & 4.62 & 5.50 & 7.02 & 6.51 & 6.21 & 2.43 & 2.93 & 4.11 \\
\hline $\mathrm{K}_{2} \mathrm{O}$ & 0.63 & 0.79 & 1.07 & 0.80 & 3.14 & 4.86 & 4.56 & 5.12 & 4.97 & 5.03 & 0.66 & 0.92 & 1.31 \\
\hline $\mathrm{P}_{2} \mathrm{O}_{5}$ & 0.25 & 0.42 & 0.56 & 0.40 & 0.93 & 0.41 & 0.28 & 0.02 & 0.01 & 0.03 & 0.37 & 0.64 & 0.73 \\
\hline LOI & 1.06 & 1.61 & 0.20 & 1.47 & 1.48 & 0.19 & 0.74 & 1.47 & 1.57 & 1.07 & 1.60 & 0.54 & 0.76 \\
\hline Alkali total & 3.29 & 3.28 & 4.48 & 3.64 & 8.69 & 9.48 & 10.06 & 12.14 & 11.48 & 11.23 & 3.09 & 3.85 & 5.42 \\
\hline $\begin{array}{c}\text { Agpaitic } \\
\text { index }\end{array}$ & 0.24 & 0.34 & 0.44 & 0.36 & 0.81 & 0.78 & 0.85 & 0.96 & 1.02 & 0.98 & 0.33 & 0.38 & 0.53 \\
\hline $\mathrm{Mg}$ number & 48.83 & 68.23 & 64.34 & 66.08 & 34.25 & 21.39 & 19.14 & 3.31 & 0.95 & 0.81 & 67.26 & 59.39 & 49.51 \\
\hline
\end{tabular}




\section{(Continued)}

\begin{tabular}{|c|c|c|c|c|c|c|c|c|c|c|c|c|}
\hline UNIT & Rift center & afic & & & Gedemsa & & & & & & & Nazreth \\
\hline Sample No. & $\begin{array}{c}\text { ET } \\
941503 \mathrm{~A} \\
\end{array}$ & $\begin{array}{c}\text { ET } \\
941502\end{array}$ & $\begin{array}{c}\text { ET } \\
1706 \\
\end{array}$ & $\begin{array}{c}\text { ET } \\
941503 B\end{array}$ & ET60 & ET54 & ET38 & ET 9865 & $\begin{array}{c}\text { ET } \\
9840 \\
\end{array}$ & ET06 & ET103 & ET94 \\
\hline Locality & D.Zeit & D.Zeit & Mojo & D.Zeit & Sololuya & Gedemsa & Alula & Gedemsa & Koka & Gedemsa & Gedemsa & Bulbula \\
\hline Rock type & basalt & basalt & basalt & basalt & rhyolite & rhyolite & obsidian & rhyolite & rhyolite & obsidian & ignimbrite & ignimbrite \\
\hline Age (Ma) & 0.6 & 0.6 & 1 & 0.5 & 0.5 & 0.6 & 0.6 & 0.5 & 0.5 & 0.5 & 0.6 & 0.5 \\
\hline $\mathrm{SiO}_{2}$ & 49.09 & 46.38 & 49.45 & 49.08 & 71.88 & 72.19 & 72.69 & 73.59 & 72.91 & 72.34 & 73.47 & 67.14 \\
\hline $\mathrm{TiO}_{2}$ & 1.35 & 1.65 & 1.95 & 2.24 & 0.33 & 0.32 & 0.31 & 0.27 & 0.35 & 0.31 & 0.33 & 0.69 \\
\hline $\mathrm{Al}_{2} \mathrm{O}_{3}$ & 16.16 & 13.00 & 17.45 & 15.88 & 12.92 & 12.85 & 10.86 & 9.57 & 9.89 & 12.61 & 9.15 & 14.26 \\
\hline $\mathrm{Fe}_{2} \mathrm{O}_{3}$ & 1.51 & 1.73 & 1.76 & 1.92 & 0.62 & 0.62 & 0.89 & 1.07 & 0.94 & 0.61 & 1.00 & 0.91 \\
\hline $\mathrm{FeO}$ & 7.70 & 8.81 & 8.96 & 9.80 & 3.21 & 3.20 & 4.59 & 5.51 & 4.81 & 3.13 & 5.16 & 4.66 \\
\hline $\mathrm{MnO}$ & 0.14 & 0.16 & 0.14 & 0.18 & 0.13 & 0.13 & 0.17 & 0.23 & 0.21 & 0.12 & 0.22 & 0.21 \\
\hline $\mathrm{MgO}$ & 9.28 & 13.93 & 6.27 & 6.36 & 0.13 & 0.12 & 0.06 & 0.11 & 0.05 & 0.06 & 0.05 & 0.52 \\
\hline $\mathrm{CaO}$ & 11.00 & 11.15 & 9.43 & 9.42 & 0.70 & 0.65 & 0.41 & 0.30 & 0.35 & 0.55 & 0.85 & 1.78 \\
\hline $\mathrm{Na}_{2} \mathrm{O}$ & 2.34 & 2.26 & 3.30 & 3.43 & 5.13 & 5.23 & 5.65 & 4.83 & 5.94 & 5.16 & 5.29 & 5.75 \\
\hline $\mathrm{K}_{2} \mathrm{O}$ & 1.17 & 0.64 & 0.91 & 1.06 & 4.95 & 4.67 & 4.30 & 4.51 & 4.55 & 5.09 & 4.48 & 3.97 \\
\hline $\mathrm{P}_{2} \mathrm{O}_{5}$ & 0.25 & 0.30 & 0.38 & 0.64 & 0.01 & 0.01 & 0.06 & 0.01 & - & 0.00 & 0.00 & 0.13 \\
\hline LOI & 0.11 & - & - & - & 0.17 & 1.12 & 0.86 & - & - & 0.22 & 0.18 & 1.17 \\
\hline Alkali total & 3.51 & 2.91 & 4.21 & 4.49 & 10.07 & 9.90 & 9.96 & 9.34 & 10.49 & 10.24 & 9.77 & 9.72 \\
\hline Agpaitic index & 0.32 & 0.09 & 0.37 & 0.43 & 1.07 & 1.06 & 1.28 & 1.34 & 1.49 & 1.11 & 1.48 & 0.96 \\
\hline Mg number & 68.23 & 73.81 & 55.51 & 53.65 & 6.61 & 6.33 & 2.30 & 3.52 & 1.86 & 3.55 & 1.67 & 16.57 \\
\hline
\end{tabular}


(Continued)

\begin{tabular}{|c|c|c|c|c|c|c|c|c|c|c|c|c|c|}
\hline UNIT & Plateau & $\begin{array}{l}\text { Addis } \\
\text { Ababa }\end{array}$ & & & Wechecha & & & & & & Rift cente & r mafic & \\
\hline Sample No. & ET1201 & ET1303 & ET1602 & ET1403 & ET1203B & ET1405 & ET1404A & ET1203A & ET1302 & ET1301 & ET1606 & ET1508 & ET1507b \\
\hline Locality & Intoto & Wechecha & Addis & Akaki & Menagesha & Yerer & Yerer & Menagesha & Wechecha & Wechecha & Wonji & Sodorei & Boku \\
\hline Rock type & basalt & basalt & basalt & basalt & benmoreite & benmoreite & benmoreite & trachyte & trachyte & rhyolite & basalt & basalt & hawaiite \\
\hline $\mathrm{Cr}$ & 32 & 672 & 331 & 491 & 5 & 20 & 17 & 19 & 16 & 19 & 558 & 245 & 36 \\
\hline $\mathrm{Ni}$ & 15 & 231 & 185 & 154 & 8 & 2 & 3 & 7 & 8 & 2 & 208 & 107 & 52 \\
\hline $\mathrm{Ba}$ & 160 & 361 & 301 & 446 & 1,001 & 89 & 1,267 & 48 & 143 & 151 & 274 & 467 & 1,456 \\
\hline $\mathrm{Nb}$ & 15.7 & 33.1 & 47.1 & 31.4 & 106.5 & 108.0 & 104.6 & 231.7 & 192.2 & 166.0 & 20.4 & 28.5 & 26.1 \\
\hline $\mathrm{Zr}$ & 110.5 & 125.6 & 232.6 & 122.4 & 481.2 & 774.8 & 745.0 & 1,104 & 965.4 & 818.4 & 117.7 & 174.9 & 157.1 \\
\hline $\mathrm{Y}$ & 15.1 & 23.7 & 23.8 & 20.7 & 65.0 & 66.2 & 82.0 & 74.9 & 204.8 & 44.3 & 21.2 & 16.3 & 28.0 \\
\hline $\mathrm{Sr}$ & 792.6 & 675.8 & 643.7 & 629.0 & 540.0 & 313.0 & 276.1 & 5.3 & 5.6 & 6.6 & 401.6 & 481.4 & 466.9 \\
\hline $\mathrm{Rb}$ & 19.2 & 16.6 & 16.6 & 16.2 & 79.0 & 119.3 & 120.1 & 189.5 & 159.3 & 151.1 & 12.0 & 16.0 & 16.9 \\
\hline $\mathrm{La}$ & 12.9 & 24.4 & 24.9 & 21.7 & - & 93.3 & 104.2 & 175.3 & 694.2 & 17.8 & 17.0 & 24.3 & 28.9 \\
\hline $\mathrm{Ce}$ & 28.7 & 47.8 & 55.9 & 45.4 & & 191.5 & 183.0 & 152.1 & 229.0 & 74.9 & 37.3 & 52.9 & 63.3 \\
\hline $\operatorname{Pr}$ & 3.7 & 5.9 & 6.9 & 5.5 & & 22.1 & 22.3 & 25.0 & 25.0 & 4.3 & 4.8 & 6.6 & 8.3 \\
\hline $\mathrm{Nd}$ & 15.8 & 24.9 & 28.3 & 23.5 & & 84.5 & 83.3 & 99.8 & 100.0 & 16.0 & 20.7 & 26.9 & - \\
\hline $\mathrm{Sm}$ & 3.6 & 5.2 & 5.8 & 5.0 & & 15.9 & 15.5 & 14.6 & 30.0 & 4.0 & 4.7 & 5.6 & - \\
\hline $\mathrm{Eu}$ & 1.3 & 1.8 & 1.9 & 1.7 & & 3.8 & 3.7 & 0.8 & 5.0 & 0.8 & 1.6 & 2.1 & 3.5 \\
\hline $\mathrm{Gd}$ & 3.5 & 5.2 & 5.5 & 4.8 & & 13.7 & 13.9 & 10.4 & 20.0 & 4.8 & 4.6 & 5.7 & 7.1 \\
\hline $\mathrm{Tb}$ & 0.5 & 0.8 & 0.8 & 0.7 & 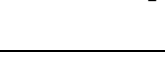 & 2.1 & 2.1 & 1.8 & 5.0 & 1.0 & 0.7 & 0.8 & 1.0 \\
\hline Dy & 3.1 & 4.4 & 4.5 & 4.2 & & 12.9 & 13.3 & 12.0 & 20.0 & 7.9 & 4.2 & 4.7 & 5.7 \\
\hline Ho & 0.6 & 0.8 & 0.8 & 0.8 & & 2.5 & 2.7 & 2.6 & 6.7 & 1.8 & 0.8 & 0.9 & 1.1 \\
\hline
\end{tabular}




\section{(Continued)}

\begin{tabular}{|c|c|c|c|c|c|c|c|c|c|c|c|c|c|}
\hline UNIT & Plateau & $\begin{array}{l}\text { Addis } \\
\text { Ababa }\end{array}$ & & & \multicolumn{2}{|l|}{ Wechecha } & \multirow[b]{2}{*}{ ET1404A } & \multirow[b]{2}{*}{ ET1203A } & \multirow[b]{2}{*}{ ET1302 } & \multirow[b]{2}{*}{ ET1301 } & \multicolumn{2}{|c|}{ Rift center mafic } & \multirow[b]{2}{*}{ ET1507b } \\
\hline Sample No. & ET1201 & ET1303 & ET1602 & ET1403 & ET1203B & ET1405 & & & & & ET1606 & ET1508 & \\
\hline Locality & Intoto & Wechecha & Addis & Akaki & Menagesha & Yerer & Yerer & Menagesha & Wechecha & Wechecha & Wonji & Sodorei & Boku \\
\hline Rock type & basalt & basalt & basalt & basalt & benmoreite & benmoreite & benmoreite & trachyte & trachyte & rhyolite & basalt & basalt & hawaiite \\
\hline Er & 1.6 & 2.3 & 1.9 & 2.2 & - & 7.2 & 8.0 & 8.1 & 17.7 & 5.9 & 2.2 & 2.2 & 2.9 \\
\hline $\mathrm{Tm}$ & 0.2 & 0.3 & 0.3 & 0.3 & - & 1.0 & 1.1 & 1.3 & 2.4 & 0.9 & 0.3 & 0.3 & 0.4 \\
\hline $\mathrm{Yb}$ & 1.3 & 1.9 & 1.8 & 1.8 & - & 6.9 & 7.4 & 8.8 & 15.6 & 6.6 & 1.9 & 2.0 & 2.5 \\
\hline $\mathrm{Lu}$ & 0.2 & 0.3 & 0.2 & 0.3 & - & 1.0 & 1.1 & 1.4 & 2.2 & 1.0 & 0.3 & 0.3 & 0.4 \\
\hline $\mathrm{Hf}$ & 2.6 & 3.0 & 5.2 & 3.0 & - & 17.6 & 17.3 & 23.2 & 21.7 & 18.5 & 2.9 & 3.5 & 3.8 \\
\hline $\mathrm{Ta}$ & 1.0 & 1.9 & 5.7 & 1.9 & - & 6.1 & 5.8 & 13.7 & 10.6 & 9.1 & 1.2 & 2.5 & 1.5 \\
\hline Th & 1.2 & 2.2 & 2.4 & 2.2 & - & 14.5 & 14.2 & 31.9 & 24.2 & 20.9 & 1.5 & 2.0 & 2.3 \\
\hline $\mathrm{U}$ & 0.3 & 0.5 & 0.6 & 0.5 & - & 3.4 & 3.4 & 3.7 & 3.4 & 2.8 & 0.4 & 0.6 & 0.4 \\
\hline $\mathrm{Zr} / \mathrm{Nb}$ & 7.04 & 3.79 & 4.94 & 3.90 & 4.52 & 7.17 & 7.12 & 4.76 & 5.02 & 4.93 & 5.77 & 6.15 & 6.02 \\
\hline \multicolumn{14}{|l|}{ Isotope } \\
\hline$(87 \mathrm{Sr} / 86 \mathrm{Sr}) \mathrm{I}$ & 0.70376 & 0.70383 & 0.70350 & 0.70368 & 0.70387 & 0.70489 & 0.70490 & 0.70504 & 0.70727 & 0.70624 & 0.70427 & 0.70441 & 0.70456 \\
\hline $\begin{array}{c}(143 \mathrm{Nd} / 144 \mathrm{Nd}) \\
\mathrm{I}\end{array}$ & 0.51222 & 0.51281 & 0.51289 & 0.51288 & 0.51264 & 0.51262 & 0.51264 & 0.51276 & 0.51273 & 0.51237 & 0.51276 & 0.51279 & 0.51270 \\
\hline
\end{tabular}




\section{(Continued)}

\begin{tabular}{|c|c|c|c|c|c|c|c|c|c|c|c|c|}
\hline UNIT & Rift cente & mafic & & & Gedemsa & & & & & & & Nazreth \\
\hline Sample No. & \begin{tabular}{|c|} 
ET \\
$941503 A$
\end{tabular} & $\begin{array}{c}\text { ET } \\
941502\end{array}$ & $\begin{array}{c}\text { ET } \\
1706\end{array}$ & $\begin{array}{c}\text { ET } \\
941503 B\end{array}$ & ET60 & \begin{tabular}{|l|} 
ET54 \\
\end{tabular} & ET38 & ET 9865 & ET 9840 & ET06 & ET103 & ET94 \\
\hline Locality & D.Zeit & D.Zeit & Mojo & D.Zeit & Sololuya & Gedemsa & Alula & Gedemsa & Koka & Gedemsa & Gedemsa & Bulbula \\
\hline Rock type & basalt & basalt & basalt & basalt & rhyolite & rhyolite & obsidian & rhyolite & rhyolite & obsidian & ignimbrite & ignimbrite \\
\hline Age (Ma) & 0.6 & 0.6 & 1 & 0.5 & 0.5 & 0.6 & 0.6 & 0.5 & 0.5 & 0.5 & 0.6 & 0.5 \\
\hline $\mathrm{Cr}$ & 298 & 822 & 114 & 139 & 14 & 9 & 28 & 13 & 12 & 16 & 13 & 15 \\
\hline $\mathrm{Ni}$ & 148 & 380 & 46 & 73 & 28 & 28 & 17 & 28 & 27 & 25 & 28 & 27 \\
\hline $\mathrm{Ba}$ & 331 & 278 & 320 & 518 & 491 & 492 & 183 & 128 & 53 & 397 & 66 & 1,246 \\
\hline $\mathrm{Nb}$ & 24.1 & 26.6 & 26.4 & 32.2 & 104.1 & 103.7 & 100.9 & 140.0 & 128.6 & 109.8 & 113.9 & 75.4 \\
\hline $\mathrm{Zr}$ & 106.1 & 109.7 & 143.8 & 165.5 & 761.2 & 764.1 & 791.3 & 1,077 & 918 & 813.8 & 668.8 & 503.1 \\
\hline $\mathrm{Y}$ & 17.6 & 19.0 & 24.4 & 28.1 & 74.8 & 74.6 & 93.5 & 60.0 & 94.3 & 82.2 & 62.7 & 48.3 \\
\hline $\mathrm{Sr}$ & 466.6 & 461.6 & 555.0 & 635.9 & 21.5 & 20.2 & 10.9 & 9.5 & 3.5 & 16.0 & 11.7 & 179.3 \\
\hline $\mathrm{Rb}$ & 20.3 & 15.7 & 15.1 & 17.3 & 115.2 & 113.6 & 111.2 & 140.2 & 120.3 & 129.9 & 128.6 & 82.9 \\
\hline $\mathrm{La}$ & 18.7 & 18.5 & 25.4 & 29.6 & 93.9 & 87.7 & 112.8 & 109.5 & 107.3 & 96.0 & - & 59.2 \\
\hline $\mathrm{Ce}$ & 37.8 & 38.1 & 48.8 & 62.6 & 185.6 & 185.6 & 226.0 & 279.8 & 224.2 & 196.1 & & 123.3 \\
\hline $\mathrm{Pr}$ & 4.5 & 4.7 & 6.5 & 7.7 & 22.0 & 20.6 & 25.0 & 25.0 & 25.0 & 22.3 & - & 14.2 \\
\hline $\mathrm{Nd}$ & 18.2 & 19.2 & 27.2 & 32.1 & 81.2 & 76.6 & 100.0 & 100.0 & 95.8 & 82.6 & - & 54.8 \\
\hline $\mathrm{Sm}$ & 3.8 & 4.1 & 5.6 & 6.6 & 15.8 & 15.2 & 20.5 & 21.2 & 19.3 & 16.6 & - & 10.9 \\
\hline $\mathrm{Eu}$ & 1.4 & 1.4 & 1.9 & 2.2 & 2.0 & 2.0 & 3.1 & 3.0 & 2.2 & 2.1 & & 3.1 \\
\hline Gd & 3.7 & 4.1 & 5.4 & 6.3 & 13.9 & 13.6 & 18.2 & 17.9 & 17.7 & 14.8 & 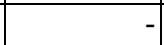 & 9.8 \\
\hline $\mathrm{Tb}$ & 0.6 & 0.6 & 0.8 & 0.9 & 2.3 & 2.2 & 3.0 & 2.9 & 2.9 & 2.5 & - & 1.6 \\
\hline Dy & 3.4 & 3.8 & 4.9 & 5.5 & 14.5 & 14.1 & 18.6 & 17.5 & 18.1 & 15.6 & - & 9.7 \\
\hline Ho & 0.7 & 0.7 & 0.9 & 1.1 & 2.9 & 2.8 & 3.7 & 3.3 & 3.7 & 3.1 & & 1.9 \\
\hline
\end{tabular}


(Continued)

\begin{tabular}{|c|c|c|c|c|c|c|c|c|c|c|c|c|}
\hline UNIT & \multicolumn{2}{|c|}{ Rift center mafic } & & & \multicolumn{2}{|l|}{ Gedemsa } & \multirow[b]{2}{*}{ ET38 } & \multirow[b]{2}{*}{ ET 9865} & \multirow[b]{2}{*}{ ET 9840} & \multirow[b]{2}{*}{ ET06 } & \multirow[b]{2}{*}{ ET103 } & \multirow{2}{*}{$\begin{array}{c}\text { Nazreth } \\
\text { ET94 }\end{array}$} \\
\hline Sample No. & $\begin{array}{c}\text { ET } \\
941503 A\end{array}$ & $\begin{array}{c}\text { ET } \\
941502\end{array}$ & $\begin{array}{c}\text { ET } \\
1706\end{array}$ & $\begin{array}{c}\text { ET } \\
941503 B\end{array}$ & ET60 & ET54 & & & & & & \\
\hline Locality & D.Zeit & D.Zeit & Mojo & D.Zeit & Sololuya & Gedemsa & Alula & Gedemsa & Koka & Gedemsa & Gedemsa & Bulbula \\
\hline Rock type & basalt & basalt & basalt & basalt & rhyolite & rhyolite & obsidian & rhyolite & rhyolite & obsidian & ignimbrite & ignimbrite \\
\hline Age (Ma) & 0.6 & 0.6 & 1 & 0.5 & 0.5 & 0.6 & 0.6 & 0.5 & 0.5 & 0.5 & 0.6 & 0.5 \\
\hline $\mathrm{Er}$ & 1.9 & 2.0 & 2.6 & 3.0 & 8.4 & 8.4 & 10.6 & 9.3 & 10.7 & 9.2 & - & 5.5 \\
\hline $\mathrm{Tm}$ & 0.3 & 0.3 & 0.4 & 0.4 & 1.2 & 1.2 & 1.5 & 1.4 & 1.6 & 1.3 & & 0.8 \\
\hline $\mathrm{Yb}$ & 1.7 & 1.8 & 2.3 & 2.7 & 8.2 & 8.2 & 10.0 & 9.6 & 10.2 & 8.9 & - & 5.4 \\
\hline $\mathrm{Lu}$ & 0.3 & 0.3 & 0.3 & 0.4 & 1.2 & 1.2 & 1.4 & 1.4 & 1.5 & 1.3 & 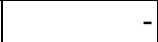 & 0.8 \\
\hline $\mathrm{Hf}$ & 2.5 & 2.6 & 3.5 & 3.9 & 18.7 & 18.5 & 19.2 & 26.4 & 22.3 & 19.9 & & 12.4 \\
\hline $\mathrm{Ta}$ & 1.4 & 1.6 & 1.5 & 1.8 & 6.1 & 6.1 & 5.9 & 8.1 & 7.5 & 6.7 & & 4.3 \\
\hline $\mathrm{Th}$ & 2.1 & 2.1 & 2.1 & 2.2 & 16.0 & 15.7 & 15.2 & 20.4 & 16.9 & 16.7 & & 9.8 \\
\hline $\mathrm{U}$ & 0.6 & 0.5 & 0.5 & 0.5 & 3.6 & 3.7 & 3.6 & 1.2 & 4.0 & 3.9 & - & 1.9 \\
\hline $\mathrm{Zr} / \mathrm{Nb}$ & 4.40 & 4.12 & 5.45 & 5.14 & 7.31 & 7.37 & 7.84 & 7.69 & 7.14 & 7.41 & 5.87 & 6.67 \\
\hline \multicolumn{13}{|l|}{ Isotope } \\
\hline $\begin{array}{c}(87 \mathrm{Sr} / 86 \mathrm{Sr}) \\
\mathrm{I}\end{array}$ & & & & 0.70476 & 0.70469 & 0.70783 & & & 0.70463 & 0.70459 & 0.70589 & \\
\hline $\begin{array}{c}(143 \mathrm{Nd} / 144 \\
\mathrm{Nd}) \mathrm{I}\end{array}$ & & & 0.51278 & 0.51278 & 0.51273 & & & 0.51282 & 0.51278 & 0.51281 & & \\
\hline
\end{tabular}




\section{(Continued)}

\begin{tabular}{|c|c|c|c|c|c|c|c|c|c|c|c|c|c|c|}
\hline UNIT & Nazreth & & & & & & Boseti & & & & & & & \\
\hline Sample No. & ET14 & $\begin{array}{c}\text { ET } \\
971602\end{array}$ & ET 117 & ET1607 & ET1608 & ET1702A & ET1504 & ET1507 & ET1505 & ET1501 & ET1506 & ET1605 & ET1604b & ET1603b \\
\hline Locality & Tafu & Kone & Barko & Harbona & Kimbo & Boku & Boseti & Boseti & Boseti & Wolenchiti & Boseti & Hada & Hada & Hada \\
\hline Rock type & trachyte & rhyolite & rhyolite & rhyolite & rhyolite & rhyolite & benmoreite & trachyte & trachyte & trachyte & rhyolite & trachyte & rhyolite & rhyolite \\
\hline $\mathrm{Cr}$ & 10 & 18 & 11 & 17 & 20 & 13 & - & 25 & 20 & 16 & 17 & 16 & 20 & 17 \\
\hline $\mathrm{Ni}$ & 28 & 1 & 28 & 1 & 2 & 26 & 10 & 2 & 1 & 2 & 4 & 2 & 2 & 3 \\
\hline $\mathrm{Ba}$ & 1,290 & 602 & 95 & 974 & 857 & 67 & 657 & 1,974 & 821 & 461 & 394 & 968 & 695 & 973 \\
\hline $\mathrm{Nb}$ & 81.7 & 126.7 & 111.9 & 114.2 & 92.1 & 129.2 & 33.8 & 85.1 & 109.1 & 92.4 & 160.8 & 88.0 & 92.3 & 91.3 \\
\hline $\mathrm{Zr}$ & 539.7 & 579.0 & 772.3 & 756.4 & 686.9 & 1,024 & 161.4 & 492.9 & 706.7 & 528.0 & 1,065 & 645.6 & 680.0 & 679.4 \\
\hline $\mathrm{Y}$ & 55.5 & 91.0 & 56.7 & 58.2 & 70.5 & 80.3 & 22.6 & 68.5 & 80.9 & 62.8 & 129.5 & 65.8 & 69.2 & 65.8 \\
\hline $\mathrm{Sr}$ & 156.3 & 32.2 & 3.0 & 21.8 & 114.9 & 3.9 & 578.4 & 28.3 & 12.8 & 6.7 & 5.4 & 110.4 & 83.2 & 100.8 \\
\hline $\mathrm{Rb}$ & 85.0 & 111.8 & 122.1 & 95.0 & 110.2 & 148.9 & 21.7 & 56.9 & 97.3 & 78.6 & 142.9 & 97.5 & 103.4 & 103.8 \\
\hline $\mathrm{La}$ & 65.7 & 91.6 & 93.6 & 82.5 & 85.3 & 106.3 & 27.4 & 61.2 & 82.4 & 65.4 & 129.8 & 73.1 & 75.9 & 74.5 \\
\hline $\mathrm{Ce}$ & 135.0 & 185.3 & 168.7 & 165.8 & 175.4 & 215.2 & 55.7 & 130.0 & 169.3 & 136.5 & 267.0 & 148.8 & 153.2 & 152.9 \\
\hline $\operatorname{Pr}$ & 15.9 & 21.1 & 23.3 & 19.8 & 20.3 & 24.8 & 6.6 & 25.0 & 19.6 & 16.0 & 15.6 & 17.0 & 17.7 & 17.4 \\
\hline $\mathrm{Nd}$ & 60.5 & 80.0 & 87.5 & 75.0 & 77.0 & 91.4 & 26.5 & 100.0 & 75.6 & 62.0 & 62.4 & 64.2 & 66.3 & 66.5 \\
\hline $\mathrm{Sm}$ & 12.2 & 16.3 & 17.0 & 14.5 & 14.9 & 17.9 & 5.4 & 24.7 & 15.6 & 12.7 & 13.2 & 12.8 & 13.3 & 13.2 \\
\hline $\mathrm{Eu}$ & 3.4 & 3.3 & 2.4 & 2.9 & 3.4 & 2.4 & 1.8 & 5.0 & 3.6 & 2.2 & 4.2 & 3.1 & 2.9 & 3.0 \\
\hline $\mathrm{Gd}$ & 11.0 & 15.3 & 14.2 & 12.3 & 13.1 & 15.9 & 5.1 & 20.0 & 14.8 & 11.7 & 12.9 & 11.9 & 12.3 & 12.1 \\
\hline $\mathrm{Tb}$ & 1.8 & 2.6 & 2.3 & 2.0 & 2.1 & 2.6 & 0.8 & 4.0 & 2.5 & 1.9 & 2.1 & 2.0 & 2.0 & 2.0 \\
\hline Dy & 11.0 & 16.8 & 13.9 & 12.5 & 13.1 & 15.9 & 4.5 & 20.0 & 15.5 & 12.0 & 13.4 & 12.5 & 13.0 & 12.6 \\
\hline Ho & 2.2 & 3.5 & 2.7 & 2.5 & 2.6 & 3.1 & 0.9 & 5.0 & 3.1 & 2.4 & 2.7 & 2.5 & 2.6 & 2.6 \\
\hline
\end{tabular}




\section{(Continued)}

\begin{tabular}{|c|c|c|c|c|c|c|c|c|c|c|c|c|c|c|}
\hline UNIT & Nazreth & & & & & & Boseti & & & & & & & \\
\hline Sample No. & ET14 & $\begin{array}{c}\text { ET } \\
971602 \\
\end{array}$ & ET 117 & ET1607 & ET1608 & ET1702A & ET1504 & ET1507 & ET1505 & ET1501 & ET1506 & ET1605 & ET1604b & ET1603b \\
\hline Locality & Tafu & Kone & Barko & Harbona & Kimbo & Boku & Boseti & Boseti & Boseti & Wolenchiti & Boseti & Hada & Hada & Hada \\
\hline Rock type & trachyte & rhyolite & rhyolite & rhyolite & rhyolite & rhyolite & benmoreite & trachyte & trachyte & trachyte & rhyolite & trachyte & rhyolite & rhyolite \\
\hline $\mathrm{Er}$ & 6.3 & 10.5 & 7.7 & 7.1 & 7.7 & 8.8 & 2.4 & 14.7 & 9.2 & 7.2 & 7.8 & 7.5 & 7.8 & 7.6 \\
\hline $\mathrm{Tm}$ & 0.9 & 1.5 & 1.2 & 1.1 & 1.1 & 1.3 & 0.3 & 2.1 & 1.3 & 1.1 & 1.1 & 1.1 & 1.1 & 1.1 \\
\hline $\mathrm{Yb}$ & 6.1 & 9.9 & 8.0 & 7.7 & 7.5 & 8.6 & 2.1 & 13.6 & 8.6 & 7.2 & 7.2 & 7.3 & 7.6 & 7.3 \\
\hline $\mathrm{Lu}$ & 0.9 & 1.5 & 1.2 & 1.2 & 1.1 & 1.3 & 0.3 & 2.0 & 1.3 & 1.1 & 1.1 & 1.1 & 1.1 & 1.1 \\
\hline $\mathrm{Hf}$ & 13.1 & 19.2 & 18.7 & 17.8 & 16.3 & 22.9 & 3.7 & 25.8 & 16.5 & 12.9 & 11.8 & 15.2 & 15.9 & 15.9 \\
\hline $\mathrm{Ta}$ & 4.7 & 7.4 & 6.3 & 6.5 & 4.6 & 7.2 & 1.9 & 9.4 & 6.3 & 5.0 & 4.9 & 5.0 & 5.3 & 5.3 \\
\hline Th & 10.8 & 15.0 & 15.9 & 12.6 & 13.4 & 14.8 & 2.5 & 19.2 & 12.4 & 9.7 & 7.6 & 12.2 & 12.7 & 12.5 \\
\hline $\mathrm{U}$ & 1.9 & 6.1 & 2.1 & 1.8 & 3.0 & 3.3 & 0.6 & 4.8 & 3.2 & 2.3 & 2.1 & 1.9 & 2.8 & 1.7 \\
\hline $\mathrm{Zr} / \mathrm{Nb}$ & 6.61 & 4.57 & 6.90 & 6.62 & 7.46 & 7.92 & 4.78 & 5.79 & 6.48 & 5.71 & 6.62 & 7.33 & 7.37 & 7.44 \\
\hline \multicolumn{15}{|l|}{ Isotope } \\
\hline$(87 \mathrm{Sr} / 86 \mathrm{Sr}) \mathrm{I}$ & 0.70502 & 0.70577 & & 0.70477 & 0.70486 & 0.70628 & 0.70478 & 0.70553 & 0.70450 & 0.70538 & 0.70416 & 0.70447 & 0.70446 & 0.70474 \\
\hline $\begin{array}{c}(143 \mathrm{Nd} / 144 \mathrm{Nd}) \\
\mathrm{I}\end{array}$ & 0.51277 & 0.51285 & & 0.51266 & 0.51281 & 0.51279 & 0.51262 & 0.51285 & 0.51286 & 0.51284 & 0.51277 & 0.51261 & 0.51280 & 0.51274 \\
\hline
\end{tabular}

